2010

\title{
Negotiation Ethics for Real World Interactions
}

Charles B. Craver

George Washington University Law School, ccraver@law.gwu.edu

Follow this and additional works at: https://scholarship.law.gwu.edu/faculty_publications

Part of the Law Commons

\section{Recommended Citation}

Charles B. Craver, Negotiation Ethics for Real World Interactions, 25 Ohio St. J. on Disp. Resol. 299 (2010).

This Article is brought to you for free and open access by the Faculty Scholarship at Scholarly Commons. It has been accepted for inclusion in GW Law Faculty Publications \& Other Works by an authorized administrator of Scholarly Commons. For more information, please contact spagel@law.gwu.edu. 


\title{
EGOTIATION ETHICS FOR REAL WORLD INTERACTIONS*
}

\author{
By Charles B. Craver**
}

\begin{abstract}
On the one hand the negotiator must be fair and truthful; on the other he must mislead his opponent. Like the poker player, a negotiator hopes that his opponent will overestimate the value of his hand. Like the poker player, . . . he must facilitate his opponent's inaccurate assessment. The critical difference between those who are successful negotiators and those who are not lies in this capacity both to mislead and not to be misled. ... [A] careful examination of the behavior of even the most forthright, honest, and trustworthy negotiators will show them actively engaged in misleading their opponents about their true positions. .. . To conceal one's true position, to mislead an opponent about one's true settling point is the essence of negotiation. ${ }^{11}$
\end{abstract}

[T] he profession should embrace an affirmative ethical standard for attorneys' professional relationships with courts, other lawyers and the public: The lawyer must act honestly and in good faith. Another lawyer ... should not need to exercise the same degree of caution that he would if trading for reputedly antique copper jugs in an oriental bazaar. . . [S] urely the professional standards must ultimately impose upon him a duty not to accept an unconscionable deal. While some difficulty in line-drawing is inevitable when such a distinction is sought to be made, there must be a point at which the lawyer cannot ethically accept an arrangement that is completely unfair to the other side. ${ }^{2}$

If we have come to a point where the vast majority of those who study negotiation across a range of disciplines would prescribe collaboration and problem-solving over haggling and contention because it produces better results

* Copyright 2009 by Charles B. Craver.

** Freda H. Alverson Professor, George Washington University Law School. J.D., 1971, University of Michigan; M. Indus. \& Lab. Rels., 1968, Cornell University School of Industrial \& Labor Relations; B.S. 1967, Cornell University.

${ }^{1}$ James J. White, Machiavelli and the Bar: Ethical Limitations on Lying in Negotiation, 1980 AMER. BAR FOUND. RES. J. 926, 927-28 (1980). "Deceitful or not, lies about price, value, and some other matters are practically sacrosanct to conventional negotiation. If lawyers were forbidden from engaging in these lies, they would be at a tremendous disadvantage when negotiating with any nonlawyer," Walter W. Steele, Jr., Deceptive Negotiating and High-Toned Morality, 39 VAND. L. REV. 1387, 1395 (1986).

2 Alvin B. Rubin, A Causerie on Lawyers' Ethics in Negotiation, 35 LA. L. REV. 577, 589, 591 (1975) (emphasis in original). 
for clients, why would the legal profession continue to allow lawyers to choose an outdated, less effective approach to negotiation? $?^{3}$

Should we base our negotiation ethics rules and practices on the current empirical reality of expectations of "generally accepted conventions" ("background norms") or should we aspire to make current practices more fair or just?

\section{INTRODUCTION}

Lawyers negotiate repeatedly. They actually engage in bargaining interactions when they do not even appreciate the fact they are negotiating. They interact with colleagues within their own firms, and they interact with prospective clients and current clients. They also negotiate on behalf of clients with external parties. Transactional attorneys work to structure diverse business arrangements, while litigators endeavor to resolve disputes. ${ }^{5}$ For decades, most law schools did not offer courses in negotiation, apparently believing that such practical lawyering skills should not - or could not - be taught in law school class settings. They seemed to think that such skills could best be learned through on-the-job training once students entered legal practice. ${ }^{6}$

3 Robet C. Bordone, Fitting the Ethics to the Forum: A Proposal for Process-Enabling Ethical Codes, 21 OHIO ST. J. DISP. RES. 1, 33 (2005) (emphasis in original).

${ }^{4}$ Carrie Menkel-Meadow, Ethics, Morality and Professional Responsibility in Negotiaton in DISPUTE RESOLUTION ETHICS 119, 120 (Phyllis Bernard \& Bryant Garth, eds., 2002).

${ }^{5}$ They are usually successful, since fewer than five percent of cases are actually resolved by trials in federal and state courts. This fact would suggest that the term "litigator" is overused today, given the fact that trial attorneys could more reasonably be characterized as "problem solvers" or "dispute resolvers."

6 When I entered full-time law school teaching thirty-five years ago, I requested the opportunity to teach a legal negotiating course similar to the one I was then teaching as an adjunct professor at the University of California, Berkeley. My new dean immediately rejected this proposal, indicating that such a practical course had no place in a law school curriculum. 
Over the past twenty-five years, most law schools have recognized the critical nature of negotiation skills, and they have established separate legal negotiation courses or incorporated negotiation training in alternative dispute resolution courses. When these courses were created, many teachers felt uncomfortable with the bargaining tactics discussed in negotiation books and being employed by students. Students who wished to obtain beneficial terms for their fictional clients over- and under-stated what they had to achieve or were willing to give up if mutual accords were going to be achieved. People like James J. White realized that the most effective way to induce students to work diligently on negotiation exercises involved a system in which the negotiation exercise results affected final course grades. ${ }^{7}$

Over the past thirty-five years, I have taught a two or three credit hour legal negotiation course. The students are assigned chapters in my book Effective Legal Negotiation and Settlement. ${ }^{8}$ We explore the impact of negotiator styles, the six stages of the negotiation process, verbal and nonverbal communication, negotiation techniques, the impact of such factors as anchoring, gain/loss framing, the endowment effect, the egocentric bias, the attribution bias, and regret aversion, specific negotiation issues such as telephone and e-mail interactions, and negotiation ethics. We contrast distributive bargaining designed to maximize own side returns with integrative bargaining designed to maximize the joint returns achieved by the parties.

${ }^{7}$ See generally James. J. White, The Lawyer as a Negotiator: An Adventure in Understanding and Teaching the Art of Negotiation, 19 J. LEGAL EDUC. 337 (1967).

${ }^{8}$ CHARLES B. CRAVER, EFFECTIVE LEGAL NEGOTIATION AND SETTLEMENT $\left(6^{\text {th }}\right.$ ed. 2009). 
During the term, the students engage in a series of negotiation exercises. Everyone receives the identical General Information which describes the relevant circumstances involved. The students are paired, and the individuals on each side receive Confidential Information pertaining to their fictional clients. The Confidential Information provides them with information concerning their respective clients, informs them of the specific issues to be negotiated, and assigns point values for each term to be addressed. Students can use these point structures to determine the overall value of any agreement achieved. They are also told how they will be evaluated if no agreement is reached. In most cases, they are told that if they do not obtain accords, they will be placed at the bottom of the individuals on their side. In other cases, they are told that nonsettlement parties will flip coins, role dice, or pull numbers out of a box containing a specified number of different nonsettlement results.

The first three or four interactions involve practice exercises designed to introduce students to the negotiation process, and these do not affect their course grades. They are then assigned five or six additional exercises that do impact their grades. At the conclusion of each bargaining interaction, the students on each side are rank ordered from high to low. If there are twenty-five pairs negotiating, the most successful students on each side get twenty-five placement points, the second highest students get twenty-four placement points, and so forth. Some exercises are conducted on a one-on-one basis, while others are done on a two-on-two basis. I provide them with partners to assist them with the more complex exercises, and to teach them how to interact effectively with persons on the same side. 
Two thirds of student course grades are determined by their comparative negotiation exercise results, with the other one-third being based on a ten to fifteen page paper they must prepare evaluating different aspects of their negotiation exercises. If students do not feel comfortable with the overt grade competition associated with the class exercises, they may take the course on a credit/no-credit basis. I inform the students that I grade generously, and guarantee the credit/no-credit students passing grades if they work on the assigned exercises and prepare acceptable class papers. I strongly urge students concerned about the competitive aspect of the grading process to take the class on a credit/no-credit basis. Due to the relatively generous grading curve we have at George Washington University, most students now take the course for a regular grade.

The students who take the course for traditional letter grades work diligently on the assigned exercises. They carefully review the General Information and Confidential Information sheets, and many do legal or factual research through Lexis, Westlaw, or the Internet. The students who take the course on a credit/no-credit basis do not work nearly as hard, and this lack of commitment is reflected in their negotiation performances. The students who take the class for letter grades achieve significantly better results on their negotiation exercises than their classmates who elect the credit/no-credit option. ${ }^{9}$

Over the past several years, I have taught a one credit hour negotiation class at George Washington University which meets for three and one-half hours on four consecutive Friday mornings. I have also taught the Peter Bronstein Negotiation Institute

9 See Charles B. Craver, The Impact of a Pass/Fail Option on Negotiation Course Performance, 48 J. LEGAL EDUC. 176 (1998). See also Charles B. Craver, The Impact of Student GPAs and a Pass/Fail Option on Clinical Negotiation Course Performance, 15 OHIO ST. J. DISP. RES. 373 (2000). 
to 120 students each year at the University of Virginia Law School which meets on two consecutive Saturdays each fall. Both of these intensive one credit hour courses must be taken on a credit/no-credit basis. Although we cover the same concepts in these courses as we do in my full semester class and the students engage in a series of similar negotiation exercises, they do not take the exercises as seriously. As I watch different pairs negotiate, I can see how relaxed they are compared to traditional grade students in my full semester class. They have a good time interacting with other students, and clearly do not worry about the actual results they achieve.

As greater numbers of law professors began to teach negotiation courses, they became uncomfortable with student competition associated with exercises that affected course grades. They apparently felt that second and third year law students should not be exposed to the types bargaining environments they would encounter when they enter legal practice. The teachers feared that such competitive interactions would be too traumatic for sensitive students. These teachers thus developed what has become known as the communitarian approach.

The communitarian style is based on the integrative bargaining concepts developed over one hundred years ago by Mary Parker Follett ${ }^{10}$ and explored in the mid1960s by Professors Walton and McKersie. ${ }^{11}$ This approach gained general law school acceptance following the publication of Getting to Yes by Roger Fisher and William

10 See JOAN C. TONN, MARY P. FOLLETT 360-388 (2003).

${ }^{11}$ See RICHARD E. WALTON \& ROBERT B. McKERSIE, A BEHAVIORAL THEORY OF LABOR NEGOTIATIONS (1965). 
Ury. ${ }^{12}$ This style is based on the theory that most negotiations do not involve conflicted issues. If negotiators go behind the stated positions, which often appear to be opposite, and explore the underlying interests of the parties, they often discover solutions beneficial to both sides. Two persons are trying to decide how to divide an orange they both want. It may seem fair to divide it in half, until they discover that one wants the pulp to make juice while the other wants the rind to make zest. This discovery permits them to give one all of the pulp and the other all of the rind. ${ }^{13}$

Communitarians believe "that negotiation is a moral and ethical process, worthy of deep philosophical, political, legal, and human respect." ${ }^{14}$ Their approach requires negotiating parties to be completely open and honest with each other with respect to their true interests and settlement intentions. ${ }^{15}$ Each side must candidly indicate the terms they desire and the true value placed on each, to enable the parties to achieve Pareto optimal

\section{ROGER FISHER \& WILLIAM URY, GETTING TO YES: NEGOTIATING AGREEMENT WITHOUT GIVING IN (1981).}

13 A similar story concerns two children trying to decide how to divide a piece of cake. It might seem fair to have one cut the cake and let the other select the piece she wants. If the right question is asked first, however, one may indicate a preference for icing and the other a preference for cake, allowing each child to get 100 percent of what he or she actually prefers.

14 Carrie Menkel-Meadow, The Ethics of Compromise in THE NEGOTIATOR'S FIELDBOOK 155, 156 (Andrea Kupfer Schneider \& Christopher Honeyman, eds., 2006).

15 See Mark Young, Sharks, Saints, and Samurai: The Power of Ethics in Negotiations, 24 NEG. J. 145, 150 (2008) (exhorting negotiators to always behave honorably simply because opponents deserve to be treated fairly). See generally Carrie Menkel-Meadow, The Lawyer as Consensus Builder: Ethics for a New Practice, 70 TENN. L. REV. 63 (2002); Gary Tobias Lowenthal, The Bar's Failure to Require Truthful Bargaining By Lawyers, 2 GEO. J. LEGAL ETHICS 411 (1988-89); Robert P. Burns, Some Ethical Issues Surrounding Mediation, 70 FORDHAM L. REV. 691 (2001). 
agreements which satisfy the underlying interests of each - i.e., "win-win" agreements instead of what are often characterized by commentators as "win-lose" accords that favor one side over the other. If negotiators are not entirely truthful with respect to their real interests and values, inefficiencies result or potentially beneficial accords are not achieved.

Communitarians do not like to engage in conventional distributive bargaining in which the opposing parties use deceptive tactics to enable them to claim more than a fair share for themselves. They have thus created a world in which negotiators have underlying interests that do not conflict with each other. ${ }^{16}$ Side A gives Side B what it prefers to have, while Side B gives Side A what it wants. The negotiators use a cooperative/problem-solving style which generates mutually beneficial and jointly efficient accords, instead of a competitive/adversarial style which produces one-sided and inefficient agreements.

Communitarians eschew deceptive bargaining tactics. They believe that attorneys should not be allowed to over- or under-state the way they actually value the different terms being exchanged, they do not think that lawyers should be permitted to misrepresent their true settlement intentions, and they believe that such tactics as bluffing should be proscribed. ${ }^{17}$ This approach is based upon the naïve belief that attorney bargaining interactions are primarily integrative, with few conflicting underlying interests. It assumes that lawyers rarely have to deal with distributive items that both

16 See generally Robert J. Condlin, Bargaining With a Hugger: The Weaknesses and Limitations of a Communitarian Conception of Legal Dispute Bargaining, or Why We Can't All Just Get Along, 9 CARDOZO J. DISP. RES. 1 (2007).

17 See generally Bordone, supra Note 3.. See also Chris Provis, Ethics, Deception and Labor Negotiation, 28 J. BUS. ETHICS 145 (Nov. 2000). 
sides value and wish to claim for themselves. It ignores the fact that in legal interactions, “opportunities for integrative bargaining are not nearly as pervasive as sometimes authoritatively asserted", ${ }^{18}$ due to the fact that monetary issues tend to dominate such circumstances.

$[\mathrm{M}]$ ost negotiations are "mixed motive"; they include both opportunities for joint gain, and opportunities for grabbing more from the other side. . [S]tragegies that are wise for creating are often opposite from those that are wise for claiming (e.g., deception about positions and power is necessary for claiming, while deception about interests is disruptive for creating). But all negotiations include both elements, and few negotiations occur where a wise negotiator would not employ at least some of each set of behaviors. Indeed, one of the more interesting challenges faced by negotiators is how to balance both of these elements. ${ }^{19}$

When they teach legal negotiation courses, communitarians value agreements that maximize the joint returns achieved and that fairly divide the different items between the negotiating parties. Students who adhere to this standard earn higher grades, while students who behave competitively and obtain terms more beneficial to themselves than to the other side earn lower grades. The students are thus rewarded for their complete openness regarding their underlying interests and settlement intentions and their ability to reach agreements that are of equal value to both sides.

This article will initially discuss the current ethical rules governing lawyer conduct during bargaining interactions, and the standards that communitarians would like

18 Gerald B. Wetlaufer, The Limits of Integrative Bargaining, 85 GEO. L.J. 369, 372 (1996).

19 Raymond A. Friedman \& Debra Shapiro, Deception and Mutual Gains Bargaining: Are They Mutually Exclusive? 11 NEG. J. 243, 247 (1995). See id. at 248-49; Gerald Wetlaufer, The Ethics of Lying in Negotiation, 75 IOWA L. REV. 1219, 1245-48 (1990); Garry T. Lowenthal, A General Theory of Negotiation Process, Strategy, and Behavior, 31 U. KAN. L. REV. 69, 75 (1982). 
to impose on practicing attorneys. It will then explore the different negotiator styles employed by legal practitioners to see which ethics approach is most reflective of real world encounters. It will then examine the way in which the Model Rules and traditional concepts of fraud should be applied to overt misrepresentations, partial disclosures, and non-disclosures. Inappropriate tactics and unconscionable agreements will then be assessed. The article will finally evaluate the ethical issues associated with the collaborative and cooperative law movements which are based on the communitarian approach.

\section{ETHICAL STANDARDS APPLICABLE TO BARGAINING INTERACTIONS}

When I teach negotiation skills to law students or to practicing attorneys, I often ask if they can lie during their interactions. They usually respond negatively. I then talk about two lawyers engaged in a negotiation where Side A is authorized to accept anything over $\$ 100,000$ while Side B is authorized to pay anything up to $\$ 130,000$. We thus have a $\$ 30,000$ zone of possible agreement between the $\$ 100,000$ and $\$ 130,000$ positions. The parties begin with small talk, then move on to the serious discussions. At an appropriate point, Side A says it can't accept anything less than $\$ 160,000$, and Side B responds that it can't go a penny over $\$ 70,000$. Both sides are pleased that they have begun the process successfully, yet they have both begun with bold-faced lies.

Audience members become uncomfortable. They all recall times they have commenced bargaining encounters with exaggerated position statements they did not expect their opponents to take literally. I then quote from Model Rule 4.1 which provides that "a lawyer shall not knowingly make a false statement of material fact or law to a 
third person."20 Rule 4.1 is a paragon of clarity: A lawyer may not lie. Comment 1

confirms this interpretation when it states that a "lawyer is required to be truthful when

dealing with others on a client's behalf ..."When is a lie not a lie? When it is by a

lawyer! Comment 2 acknowledges that attorneys involved in bargaining interactions have

different expectations.

Whether a particular statement should be regarded as one of fact can depend on the circumstances. Under generally accepted conventions in negotiation, certain types of statements ordinarily are not taken as statements of material fact. Estimates of price or value placed on the subject of a transaction and a party's intentions as to an acceptable settlement of a claim are ordinarily in this category, ... 21

20 See THOMAS D. MORGAN \& RONALD D. ROTUNDA, 2008 SELECTED STANDARDS ON PROFESSIONAL RESPONSIBILITY 92 (2008). See also Model Rule 8.4(c) which states that "[i]t is professional misconduct for a lawyer to: . . . (c) engage in conduct involving dishonesty, fraud, deceit, or misrepresentation." See id. at 128.

Negotiators commonly hide their true level of dependency and commonly exaggerate the value of their options in the event of no agreement, their willingness and ability to choose other options, and the likelihood that their constituents (whose supposed demands may even be fabricated) will disapprove of concessions under discussion. ...

[W] hether deception is considered ethical or not depends on the context, not the act of deceiving.

Friedman \& Shapiro, supra Note 19, at 245.

21 See MORGAN \& ROTUNDA, supra Note 20, at 93. See also Maurice E. Schweitzer \& Rachel Croson, Curtailing Deception: The Impact of Direct Questions on Lies and Omissions, 10 INTL. J. CONFLICT MGT. 225, 227 (1999) (“[N]egotiators typically consider lies about one's reservation price to be acceptable, but consider fabrications about material facts to be unethical."); Brian C. Haussmann, Note: The ABA Ethical Guidelines for Settlement Negotiations: Exceeding the Limits of the Adversarial Ethic, 89 CORNELL L. REV. 1218 (2004). 
Although Rule 4.1 unequivocally proscribes lawyer prevarication, Comment 2 excludes puffing, embellishment, and dissembling with respect to a negotiator's true settlement objectives. ${ }^{22}$ This Comment acknowledges the reality of bargaining interactions between legal practitioners.

$[\mathrm{N}]$ egotiation often cannot take place if the parties must reveal the existence of a principal, their true asking price, or their intention regarding settlement throughout the bargaining process. Deception concerning value as well as deception concerning settlement point in particular are consistent with functionalism because they are recognizable as bargaining techniques and allow accurate information to be achieved through bargaining. ${ }^{23}$

The truly ironic aspect of this exception to Rule 4.1 concerns the fact that there are really only two things that are material when attorneys negotiate. The legal, factual, economic, political, and cultural issues are all secondary. What each participant must ascertain is the degree to which the other values each of the items being discussed and the amount of each that must be conceded if an agreement is to be achieved. Nonetheless, most practicing lawyers do not expect such candor. They also realize how difficult it is for state bar associations to regulate this area due to the private nature of bargaining interactions.

If one negotiator lies to another, only by happenstance will the other discover the lie. If the settlement is concluded by negotiation, there will be no trial, no public testimony by conflicting witnesses, and thus no opportunity to examine the truthfulness of assertions made during the negotiations. Consequently, in

22 See RONALD D. ROTUNDA, PROFESSIONAL RESPONSIBILITY 167-68 (1995); Gary T. Lowenthal, A General Theory of Negotiation Process, Strategy, and Behavior, 31 KAN. L. REV. 69, 101 (1982); Geoffrey C. Hazard, Jr., The Lawyer's Obligation to Be Trustworthy When Dealing With Opposing Parties, 33 S. CAR. L. REV. 181, 183 (1981); Raymond A. Friedman \& Debra L. Shapiro, Deception and Mutual Gains Bargaining: Are They Mutually Exclusive? 11 NEG. J. 243, 245 (1995).

23 Eleanor Holmes Norton, Bargaining and the Ethic of Process, 64 N.Y.U. L. REV. 493, 537 (1989). 
negotiation, more than in other contexts, ethical norms can probably be violated with greater confidence that there will be no discovery and punishment. ${ }^{24}$

Although lawyer prevarication during bargaining interactions rarely results in bar disciplinary action, practitioners recognize that other risks are associated with inappropriately dishonest negotiating conduct. Whether attorneys function as generalists in smaller communities or specialists in larger areas, they begin to see the same persons repeatedly. If someone is discovered misrepresenting what the other side has the right to know, their reputation will suffer. ${ }^{25}$ The persons who discern the violation of trust are likely to tell others in their own firm. They and their colleagues will often tell lawyers in other firms. When negotiators can no longer be trusted with respect to representations pertaining to material factual, economic, or legal issues, they will find it difficult to interact with others. Instead of accepting what such individuals say, opponents have to verify everything they assert. Instead of relying on literal or figurative handshakes, all agreements have to be reduced to writing and signed. The negotiation process is substantially undermined, and bargaining interactions take longer and are more difficult.

When I teach my negotiation class, I have the Model Rules in force. If a student is accused of a violation, a trial would take place in front of the class. In all the years I have taught my course, I have never had to conduct a trial. Instead of filing formal charges of deceit, the accusers simply raise the issues informally before the class. The accusers and the accused are permitted to explain their positions, and I ask class members whether

24 James J. White, supra Note 1, at 926.

25 See Peter C. Cramton \& J. Gregory Dees, Promoting Honesty in Negotiation: An Exercise in Practical Ethics, 3 BUS. ETHICS Q. 359, 369 (1993). 
they think the conduct in question was appropriate or inappropriate. In most instances, students suggest that the challenged statements involved mere "puffing" or acceptable "embellishment." On rare occasions, however, they indicate a belief that the misrepresentations were improper. By the end of the semester, the students being discussed end up with one or two nonsettlements simply because their future opponents do not trust their representations and are hesitant to enter into agreements with them. If they cannot be sure of the fundamental information being conveyed by these persons, they do not feel comfortable interacting with them. ${ }^{26}$ These results graphically demonstrate to everyone the importance of relative honesty. While puffing and embellishment do not undermine future interactions, inappropriate mendacity makes it difficult for disreputable actors to achieve future accords. ${ }^{27}$

Basic trust is essential to bargaining interactions. ${ }^{28}$ The participants have to be willing to disclose their true needs and interests if the negotiators hope to achieve mutual

${ }^{26}$ See Carol M. Rose, Lecture: Trust in the Mirror of Betrayal, 75 B.U. L. REV. 531, 539-41 (1995).

27 See Debra L. Shapiro, Blair H. Sheppard \& Lisa Cheraskin, Business on a Handshake, 8 NEG. J. 365, 366-67 (1992) (discussing the degree to which mutual trust enables business partners to interact with each other efficiently and with minimal need for monitoring); Menkel-Meadow, supra Note 4, at 160 ("[L]awyers who are perceived as unethical are also perceived as ineffective."). See also David A. Lax \& James K. Sebenius, Three Ethical Issues in Negotiation, 2 NEG. J. 363, 364 (1986): “[A] lie always leaves a drop of poison behind, and even the most dazzling diplomatic success gained by dishonesty stands on an insecure foundation, for it awakes in the defeated a party a sense of aggravation, a desire for vengeance, and a hatred which must always be menace to his foe...." (quoting Francois de Callieres).

${ }^{28}$ See generally Roy Lewicki, Trust and Distrust in THE NEGOTIATOR'S FIELDBOOK 191, 196-99 (Andrea Kupfer Schneider \& Christopher Honeyman, eds., 2006). "[H]igher levels of trust make negotiation easier, while lower levels of trust make negotiation more difficult." Id. at 197. 
accords - especially if they hope to generate efficient agreements. ${ }^{29}$ If one side does not trust the other, it will be hesitant to disclose its own confidential information and underlying values, fearing exploitation by manipulative and less candid opponents. On the other hand, negotiators must be careful, even when interacting with honest opponents, not to be too forthcoming, lest they naively permit skilled adversaries to claim an excessive share of the surplus involved. ${ }^{30}$

Communitarian professors I know do not simply require their students to comply with Model Rule 4.1 and the exceptions set forth in Comment 2 with respect to bargaining interactions. They instead proscribe traditional "puffing," "embellishment," and bluffing. They require their students to be entirely candid regarding their underlying interests, the degree to which they value those interests, and the terms they have to obtain if minimally acceptable agreements are to be achieved. They praise students who generate efficient agreements that divide the items to be negotiated on a relatively equal basis. They indicate that students who obtain one-sided accords favoring their own sides will be down-graded, even if they obtain these results honestly.

The Model Rules are somewhat ambiguous when it endeavors to define the duty owed by attorneys to their clients. In the Preamble, it states that when negotiating on

29 See Lee Ross \& Constance Stillinger, Barriers to Conflict Resolution, 7 NEG. J. 389, 391 (1991); Catherine H. Tinsley, Jack J. Cambria \& Andrea Kupfer Schneider, Reputations in Negotiation in THE NEGOTIATOR'S FIELDBOOK (Andrea Kupfer Schneider \& Christopher Honeyman, eds.) 203, 207-209 (2006).

30 See Scott R. Peppet, Lawyers' Bargaining Ethics, Contract, and Collaboration: The End of the Legal Profession and the Beginning of Professional Pluralism, 90 IOWA L. REV. 475, 482-83 (2005); Geoffrey M. Peters, The Use of Lies in Negotiation, 48 OHIO ST. L.J. 1, 32, 36 (1987); Chris Provis, Ethics, Deception and Labor Negotiation, 28 J. BUS. ETHICS 145, 147 (2000). 
behalf of a client, "a lawyer seeks a result advantageous to the client but consistent with requirements of honest dealings with others." ${ }^{, 31}$ Rule 1.3 indicates that "[a] lawyer shall act with reasonable diligence . . in representing a client." 32 Comment 1 expands upon this fiduciary obligation.

A lawyer should ... take whatever lawful and ethical measures are required to vindicate a client's cause or endeavor. A lawyer must also act with commitment and dedication to the interests of the client and with zeal in advocacy upon the client's behalf. A lawyer is not bound, however, to press for every advantage that might be realized for a client. For example, a lawyer may have authority to exercise professional discretion in determining the means by which a matter should be pursued. The lawyer's duty to act with reasonable diligence does not require the use of offensive tactics or preclude the treating of all persons involved in the legal process with courtesy and respect. ${ }^{33}$

I believe that the general obligations set forth in the Preamble and in Rule 1.3 and

Comment 1 oblige attorneys to seek terms beneficial to their own clients when they

negotiate on behalf of those persons. ${ }^{34}$ I think this is true whether they are acting in an advocate capacity (e.g., representing a client in litigation) or a nonadvocate capacity.

When acting in a nonadvocate capacity on behalf of a client, a lawyer must, within the established constraints on professional behavior, attempt to achieve the client's objectives, unless to do so would require that the lawyer use unfair, unconscionable, or unjust, though not unlawful, means or that the client achieve unfair, unconscionable, or unjust, though not unlawful, ends, in which event the lawyer need not accept or continue the representation." 35

31 MORGAN \& ROTUNDA, supra Note 20, at 3.

${ }^{32} I d$. at 15.

33 Id. at 15. See Menkel-Meadow, supra Note 4, at 126-27.

34 "A negotiator-agent is under a duty to act solely for the benefit of the client-principal in all matters within the scope of the agency." Rex R. Perschbacher, Regulating Lawyers' Negotiations, 27 ARIZ. L. REV. 75, 83 (1985).

35 See Murray L. Schwartz, The Professionalism and Accountability of Lawyers in WHAT'S FAIR: ETHICS FOR NEGOTIATORS 329, 333 ((Carrie Menkel-Meadow \& Michael Wheeler, eds., 2004) (emphasis in original). 
"Professionalism means that a lawyer should . . zealously and competently use all lawful means to protect and advance the client's lawful interests." ${ }^{36}$ While legal representatives are not required to strive for entirely one-sided agreements favoring their own clients, I do not think they should forego terms that favor their own clients merely because they personally desire to divide the issues in an egalitarian manner. "Any deviation from [the] current norm would jeopardize the coveted attorney-client relationship and change the role of an attorney from that of an advocate to one of 'social policeman'. " ${ }^{37}$ If their clients were to instruct them to divide the terms equally, this would be fine. On the other hand, where clients wish to obtain accords that advance their own interests, their attorneys should work to accomplish that objective. While legal practitioners may not employ unethical tactics - and need not resort to unprofessional or offensive behavior - I believe they have an ethical duty to seek terms advantageous to their own clients. ${ }^{38}$

36 Monroe H. Freedman, Professionalism in the American Adversary System, 41 EMORY L.J. 467, 470 (1992). See W. Bradley Wendel, Public Values and Professional Responsibility, 75 NOTRE DAME L. REV. 1, 8-9 (1999); Robert J. Condlin, Bargaining in the Dark: The Normative Incoherence of Lawyer Dispute Bargaining Role, 51 MD. L. REV. 1, 3, 68-72 (1992).

37 Paul Rosenberger, Note \& Comment: Laissez- "Fair": An Argument for the Status Quo Ethical Constraints on Lawyers as Negotiators, 13 OHIO ST. J. DISP. RES. 611, 614 (1998). "Attorneys who naively believe that no deception is proper during bargaining encounters place themselves and their clients at a distinct disadvantage, because they permit their less candid opponents to obtain settlements and 'transcend the terms to which they are objectively entitled'." Id. at 626.

38 See W Bradley Wendel, Public Values and Professional Responsibility, 75 NOTRE DAME L. REV. 1, 58-67 (1999). 
Negotiating attorneys have no obligation to act in a win-lose manner designed to deprive opposing parties of fair terms simply to satisfy the desires of vindictive clients. Nor do they ever have to act in an inappropriate fashion. All proficient negotiators recognize that they should always behave professionally and strive for efficient agreements that maximize the joint returns achieved by the different parties. This leaves opponents more satisfied with what they received, and makes it more likely that they will honor the accords achieved. Nonetheless, if negotiating attorneys can professionally and ethically obtain more generous terms for their own clients, I believe they are obliged to do so.

When I teach my graded negotiation class, I am amazed how diligently students work to negotiate agreements that favor their own clients. I am also pleased at how efficient most of their accords are, because I emphasize the communitarian theory of bargaining efficiency and encourage students to maximize opponent returns when this can be accomplished at minimal cost to themselves. On rare occasions, students are so deceptive regarding their true interests and settlement intentions that they achieve inefficient agreements that place the persons on both sides below average. We then discuss what they could have done to avoid such a situation. By the end of the term, the students generally achieve highly efficient agreements that even communitarians would respect - but they strive for accords that are more favorable to their own clients than to the other side. In this regard, they do contravene a basic tenet of communitarian bargaining.

\section{IMPACT OF NEGOTIATOR STYLES ON BARGAINING INTERACTIONS}


Most negotiation books and negotiation teachers divide negotiators into two stylistic groups: cooperative/problem-solvers and competitive/adversarials. Cooperative/problem-solvers, who most closely resemble communitarians, are epitomized by Getting to Yes and Beyond Winning. ${ }^{39}$ Such negotiators move psychologically toward their opponents, and they strive to maximize the returns achieved by both sides. They begin with realistic opening positions and seek reasonable and fair results. They behave in a courteous and professional manner, and rely upon objective criteria to enable them to reason with their opponents. They eschew threatening behavior, and are open and trusting. They try to maximize the disclosure of critical information, to enable the participants to explore their respective underlying interests in an effort to achieve Pareto efficient agreements. They explore different alternatives that may allow the participants to expand the overall pie through exchanges that simultaneously advance the interests of both sides. For example, when money is an issue, they consider the use of future payments or in-kind payments that would effectively satisfy the underlying interests of the party seeking cash.

The competitive/adversarial style is epitomized by books like Start With No and ${ }^{40}$ Secrets of Power Negotiating. ${ }^{41}$ Such negotiators move psychologically against their opponents, and they work to maximize their own side's returns. They begin their

39 ROBERT H. MNOOKIN, SCOTT R. PEPPET \& ANDREW S. TULUMELLO, BEYOND WINNING: NEGOTIATING TO CREATE VALUE IN DEALS AND DISPUTES (2000). See also Carrie Menkel-Meadow, Toward Another View of Legal Negotiation: The Structure of Problem Solving, 31 U.C.L.A. L. REV. 754 (1984).

40 JIM CAMP, START WITH NO (2002).

41 ROGER DAWSON, SECRETS OF POWER NEGOTIATING (2d ed. 2001). 
interactions with unreasonable opening positions, and seek extreme results favoring their own side. They often behave in an adversarial and competitive manner. They focus primarily on their own positions, and often resort to threats. They are closed, untrusting, and manipulative. They minimize the disclosure of their own information, and they try to achieve their own goals while making minimal concessions to the other side.

Competitive/adversarial negotiators often engage in disingenuous game-playing. They conceal negative information and overstate their positive information. In their effort to advance their own interests, they may ignore alternative formulations that might benefit their opponents if those options do not advance their own interests. Their primary objective is the advancement of their own situations, and they care little about the results achieved by their opponents.

The first major empirical study of lawyer negotiator styles was conducted in 1976 by Gerald Williams in Phoenix. ${ }^{42}$ Williams asked attorneys to classify lawyers with whom they had recently interacted. Sixty-five percent of practitioners were characterized as cooperative/problem-solvers, twenty-four percent as competitive/adversarial, and eleven percent were not placed in either category. ${ }^{43} \mathrm{He}$ then asked his respondents to indicate which of these individuals were effective negotiators, average negotiators, and ineffective negotiators. Fifty-nine percent of cooperative/problem-solvers were rated effective, thirty-eight percent were rated average, and three percent were rated ineffective. Only twenty-five percent of competitive/adversarials were rated effective, forty-two percent were rated average, and thirty-three percent were rated ineffective.

${ }^{42}$ GERALD R. WILLIAMS, LEGAL NEGOTIATION AND SETTLEMENT (1983).

${ }^{43}$ See id. at 19. 
In 1999, Andrea Schneider replicated the Williams' study with attorneys in Milwaukee and Chicago. ${ }^{44}$ She found that sixty-four percent of attorneys were described by their peers as cooperative/problem-solvers, while thirty-six percent were considered competitive/adversarial. ${ }^{45}$ Fifty-four percent of cooperative/problem-solvers were rated effective, versus only nine percent of competitive/adverarials, while only four percent of cooperative/problem-solvers were rated ineffective compared to fifty-three percent of competitive/adversarials. $^{46}$

When the Williams and Schneider studies are compared, it is interesting to note two significant changes. While the proportion of effective cooperative/problem-solvers declined slightly from the 1976 study to the 1999 study, from fifty-nine percent to fiftyfour percent, the proportion of effective competitive/adversarials dropped from twentyfive percent to nine percent. ${ }^{47}$ At the other extreme, while the proportion of ineffective cooperative/problem-solvers increased slightly from 1976 to 1999, from three percent to four percent, the proportion of ineffective competitive/adversarials rose from thirty-three percent to fifty-three percent.

The empirical findings by Williams and Schneider seem to support the communitatian claim that effective negotiators generally employ a cooperative/problemsolving style which encourages complete openness and a desire to maximize the joint

\footnotetext{
44 Andrea Kupfer Schneider, Shattering Negotiation Myths: Empirical Evidence on the Effectiveness of Negotiator Style, 7 HARV. NEG. L. REV. 143 (2002).

45 See id. at 163.

${ }^{46}$ Id. at 167.

${ }^{47}$ Ibid.
} 
returns achieved. A closer examination of their findings, however, suggests that many wolves may be disguised as sheep. Both Williams and Schnedier asked the effective negotiators from both groups to list their major goals. The number one objective for effective competitive/adversarials was predictably to maximize their own returns. ${ }^{48}$ This factor is the quintessential characteristic of competitive negotiators. Nonetheless, when effective cooperative/problem-solvers listed their primary goals, they indicated that maximizing their own returns was their second objective - just behind their desire to maintain ethical standards. ${ }^{49}$ A closer examination of these factors has caused Williams and me to recognize the existence of a hybrid stylistic category between cooperative/problem-solving and competitive/adversarial, which combines the optimal traits of both.

Competitive/problem-solvers are negotiators who seek competitive objectives the maximizing of their own returns - but do so in a non-adversarial manner. They also strive to maximize opponent returns - once they have achieved their own primary goals. ${ }^{50}$ These persons are more open than competitive/adversarials, but less forthcoming than true cooperative/problem-solvers. They indicate which items they really hope to obtain, recognizing that such disclosures are critical if the parties hope to achieve efficient agreements, ${ }^{51}$ but they over- and under-state true client values for strategic purposes.

48 See WILLIAMS, supra Note 42, at 23; Schneider, supra Note 44, at 179.

49 See WILLIAMS, supra Note 42, at 20; Schneider, supra Note 44, at 170.

50 See GERALD R. WILLIAMS \& CHARLES B. CRAVER, LEGAL NEGOTIATING 64-65 (2007).

51 See Alan Strudler, On the Ethics of Deception in Negotiation, 5 BUS. ETHICS Q. 805, 814 (1995). 
When competitive/problem-solvers interact with naïve cooperative/problemsolvers, they try to exploit their opponents' openness. ${ }^{52}$ They work to create value in the Getting to Yes tradition, but then employ disingenuous tactics to claim more of the bargaining surplus than they give to their opponents. ${ }^{53}$ Unsuspecting lawyers do not appreciate how manipulative competitive/problem-solvers are. They thus classify these adroit negotiators as cooperative/problem-solvers. They think these persons are being completely open and forthright, when they are not being so candid. They thus reciprocate the seeming openness of such bargainers, without realizing that their openness is not being entirely reciprocated. ${ }^{54}$ They think that these individuals are trying to achieve "winwin" results, when they are actually seeking "WIN-win" distributions. ${ }^{55}$

52 See Steven Hartwell, Understanding and Dealing With Deception in Legal Negotiation, 6 OHIO ST. J. DISP. RES. 171, 173-75, 185-86 (1991).

$53[$ E]ven within the range of circumstances in which there are significant opportunities for integrative bargaining, the bargainer must almost always engage in distributive bargaining as well. Therefore, it is in the bargainer's self-interest not just to adopt the tactics of openness and truth-telling that are said to be appropriate to integrative bargaining, but somehow also to adopt the tactics of truth-hiding and dissimulation that are said to be appropriate to distributive bargaining.

Wetalufer, supra Note 18, at 390-91. See Lowenthal, supra Note 19, at 82; Robert J. Condlin, supra Note 16, at 65-66; Raymond A. Friedman \& Debra L. Shapiro, supra Note 19, at 247-250.

${ }^{54}$ See Tinsley, Cambria \& Schneider, supra Note 29, at 207-08 (indicating how much more open cooperative/problem-solvers are when they think they are interacting with other cooperative/problem-solvers).

55 See RONALD M. SHAPIRO \& MARK A. JANKOWSKI, THE POWER OF NICE 5 (2001). 
Kieth Allred found this approach to function effectively when he conducted empirical studies of factors associated with proficient negotiators. He explored the degree to which skilled negotiators employ "strategic practices" designed to enable them to claim more value for themselves and "integrating and accommodating practices" designed to maximize the joint returns achieved. He found that the most capable negotiators were considered by opponents to use primarily "integrating and accommodating practices," even though these interactors admitted that they employed "strategic practices" to advance their own interests. ${ }^{56}$

Haggling permits bargainers to learn about, adjust to, and accommodate the interests of other bargainers. It permits them to change minds, weaken convictions, make trades, call attention to facts not fully considered, revive considerations dismissed prematurely, and express the nature of their interests and the intensity of their resolve. ${ }^{57}$

The findings of Williams and Schneider would strongly suggest that a number of lawyers who agree to abide by collaborative or cooperative law communitarian standards of conduct are somewhat disingenuous. They do not begin with the more extreme positions employed by competitive/adversarials, but they do not begin with the truly reasonable positions articulated by real cooperative/problem-solvers. They instead begin with somewhat over-stated demands or under-stated offers. They do acknowledge their real objectives, but under- and over-state the degree to which they desire those items. They are quite efficient at creating value, as they get the important terms on the

${ }^{56}$ See Keith G. Allred, Distinguishing Best and Strategic Practices: A Framework for Managing the Dilemma Between Creating and Claming Value, 2000 NEGOT. J. 387, 394-95 (2000).

57 Robert J. Condlin, "Every Day and in Every Way We Are All Becoming Meta and Meta," or How Communitarian Bargaining Theory Conquered the World (of Bargaining Theory), 23 OHIO ST. J. DISP. RES. 231, 268 (2008). 
bargaining table. On the other hand, they subtly employ manipulative techniques

designed to allow them to claim more than their fair share of the joint value that has been discovered. ${ }^{58}$

Why are competitive/problem-solvers able to achieve their one-sided objectives without being obvious to opposing attorneys? They intuitively recognize the fact that negotiators usually judge their satisfaction with bargaining results more by the degree to which they think the process was fair and respectful than by the objective value to the terms they actually obtained. ${ }^{59}$ Competitive/problem-solvers are pleasant and respectful negotiators. They eschew openly competitive tactics, and behave as if they are cooperative/problem-solvers. Their opponents are so pleased by the way these individuals behave and the way in which the negotiation process develops that they over-value the objective value of the results they actually obtain.

It is easy to understand why communitarians believe that two-thirds of legal negotiators employ the cooperative/problem-solving style they respect, even though many of the negotiators placed in this category actually employ the competitive/problemsolving style. These persons seem to be entirely open and interested in the generation of fair and efficient agreements that maximize the joint returns achieved by the parties. They always behave in a respectful and professional manner. They do not seem to over- or under-state their true needs, nor do they appear to misrepresent their actual settlement

58 See Wetlaufer, supra Note 19 , at 1228-29.

59 See generally Rebecca Hollander-Blumoff \& Tom R. Tyler, Procedural Justice in Negotiation: Procedural Fairness, Outcome Acceptance, and Integrative Potential, 33 LAW \& SOC. INQUIRY 473 (2008); Nancy A.Welsh, Perceptions of Fairness in THE NEGOTIATOR'S FIELDBOOK 165, 170-71 (Andrea Kupfer Schneider \& Christopher Honeyman, eds. 2006). 
intentions. When they are successful, their opponents have no idea how adroitly these proficient bargainers have used subtly manipulative tactics to advance their own interests.

\section{OVERT MISREPRESENTATIONS, PARTIAL DISCLOSURES, NONDISCLOSURES, AND INAPPROPRIATE ACCESS TO OPPONENT INFORMATION}

When I teach negotiating skills to students and practicing lawyers, I often indicate that I have never participated in a legal negotiation - as an advocate or mediator - where both sides did not lie, yet I have encountered almost no attorneys I thought were dishonest. ${ }^{60}$ This seeming contradiction is based upon the fact that they have all engaged in "puffing" and "embellishment." They have over- and under-stated client values, and misstated their true settlement intentions, but have almost never misrepresented other factual or legal issues of a material nature.

In certain bargaining situations, we ... play ... mutually deceptive roles; . . . [F]alse claims are a convention; . . If buyers and sellers bargain knowingly and voluntarily, one would be hard put to regard as misleading their exaggerations, false claims to have given their last bid, or words of feigned loss of interest. Both parties have then consented to the rules of the game. ${ }^{61}$

As noted earlier, while Rule 4.1 prohibits the knowing misrepresentation of material fact or law, Comment 2 expressly recognizes that statements regarding client values and settlement intentions made during bargaining interactions do not concern

\footnotetext{
60 "Bargaining is a unique process in which the parties engage in stylized strategic behavior and use practices such as bluffing, puffing, and withholding information as a matter of course." Eleanor Holmes Norton, Bargaining and the Ethics of Process, 64 N.Y.U. L. REV. 493, 506 (1989). See Scott R. Peppet, Mindfulness in the Law and ADR: Can Saints Negotiate? A Brief Introduction to the Problems of Perfect Ethics in Bargaining, 7 HARV. NEG. L. REV. 83, 91-92 (2002).
}

${ }^{61}$ SISSELA BOK, LYING: MORAL CHOICE IN PUBLIC AND PRIVATE LIFE 138 (1978). 
material fact. ${ }^{62}$ It is thus ethical for negotiating attorneys to deliberately misrepresent such matters. They may do this overtly, partially, or through the nondisclosure of information.

\section{A. Overt Misrepresentations}

Assume that two attorneys are negotiating a marital dissolution for their respective clients. May one lawyer ethically indicate that her client desires joint custody of the young children, even though her client does not, hoping to use this issue to obtain other terms she actually desires? Since this matter concerns client values, the misrepresentation does not involve material fact. Suppose the lawyer knows that her client has $\$ 50,000$ in a secret bank account. Could she deny the existence of that account or understate the actual amount in it? These misrepresentations would clearly pertain to material facts and would thus contravene Rule 4.1. Such misstatements of material fact could also expose the client to a suit for fraud, based upon the material misrepresentation that was reasonably relied upon by the other spouse to his or her detriment.

Similar factual issues could easily arise in a personal injury case. May a plaintiff attorney embellish the discomfort associated with a sprained ankle suffered by the claimant due to the defendant's negligence? Clearly yes, so long as the statements are not entirely beyond the bounds of anything reasonable persons would characterize as mere puffing. Could the plaintiff attorney falsely state that the claimant's ankle is broken? Not without contravening Rule 4.1 and exposing his client to an action for fraud, since this would involve a misrepresentation of material fact. Suppose the plaintiff's ankle has almost healed, and that person is skiing down the slopes in Colorado. Could the claimant

62 See Notes 20 \& 21, and accompanying text, supra. 
attorney indicate that his client is only able to move with the assistance of crutches and special attachments to the feet? Such factual statements would certainly be considered improper and fraudulent, since they go well beyond puffing and are contrary to the real circumstances.

Suppose an attorney is negotiating the sale of a business for a client. The owner of the firm would like to obtain $\$ 50$ million, but would seriously consider offers in the $\$ 40$ to $\$ 45$ million range. Could the business lawyer tell a prospective buyer that her client would not accept anything less than $\$ 55$ million? The answer is clearly yes, since this statement concerns client settlement intentions that do not constitute material information within the meaning of Rule $4.1 .^{63}$ Could she state that other parties will undoubtedly be interested in her client's firm, even if no one else has yet contacted her client about a possible purchase? Most lawyers would consider such a statement to be mere puffing and permissible under acceptable negotiation ethical standards, even though such positional misstatements would be likely to help the speaker obtain an advantage at the bargaining table. ${ }^{64}$ It would similarly be acceptable to most persons for the seller's representative to talk generally about the golden future of the business, even if she somewhat over-stated

\footnotetext{
63 "An obligation to negotiate "in good faith" nixes trickery and certain forms of obduracy, ... but it does not require one side in negotiations to reveal its bargaining strategy or reservation price, ..." PSI Energy, Inc. v. Exxon Coal USA, Inc., 17 F.3d 969, 973 ( $7^{\text {th }}$ Cir. 1994). See Russell Korobkin, Michael L. Moffitt \& Nancy A. Welsh, The Law of Bargaining in THE NEGOTIATOR'S FIELDBOOK 183, 184 (Andrea Kupfer Schneider \& Christopher Honeyman, eds., 2006).

64 See Roy J. Lewicki \& Robert J. Robinson, Ethical and Unethical Bargaining Tactics: An Empirical Study, 17 J. BUS. ETHICS 665, 666-67 (1998); Alan Strudler, Incommensurable Goods, Rightful Lies, and the Wrongfulness of Fraud, 146 U. PA. L. REV. 1529, 1540-41 (1998).
} 
the actual situation, since such embellishments are normally not considered to concern statements of material fact. $^{65}$

If the firm attorney obtains a $\$ 42$ million offer from one party, may she indicate that her side has an offer from a different party when they have not received any such offer? When I have discussed this question with corporate counsel at continuing legal education programs, the vast majority suggest that such a misstatement would not be appropriate. It is not mere puffery, but concerns an issue of material fact - whether another party has made a definitive offer to purchase the business in question. I agree with this viewpoint. While it is almost certainly acceptable to indicate that other parties would have an interest in the firm, with such a general statement constituting mere puffery, it is inappropriate for the lawyer to make a knowingly false statement regarding the existence of another bidder.

Suppose the seller receives an offer of $\$ 45$ million form another party. Could the firm attorney tell the $\$ 42$ million bidder that they have received a $\$ 50$ million offer? I believe that such a deliberate misrepresentation would both contravene Rule 4.1 and

65 See, e.g., Royal Business Machines v. Lorraine Corp., 633 F.2d 34, 42 ( $7^{\text {th }}$ Cir. 1980); Vaughn v. General Foods Corp., 797 F.2d 1403 ( $7^{\text {th }}$ Cir. 1986); Vulcan Metals Co. v. Simmons Mfgr. Co., 248 F. 853 (2d Cir. 1918).

It is common knowledge and may always be assumed that any seller will express a favorable opinion concerning what he has to sell; and when he praises it in general terms, without specific content or reference to facts, buyers are expected to and do understand that they are not entitled to rely literally upon the words.

RESTATEMENT (Second) OF TORTS $\S 542 \mathrm{cmt}$. e. While statements of opinion do not usually give rise to actionable fraud, more specific statements upon which listeners may reasonably rely may be actionable. See, e.g., James v. Lifeline Mobile Medics, 341 Ill.App.3d 451, 275 Ill.Dec. 230, 792 N.E.2d 461 (2003) (misrepresentation regarding defendant's pending bankruptcy during settlement negotiations actionable, since such a specific statement involved more than mere statement of opinion). 
expose her client to a suit for fraud based on the clearly material nature of this

misrepresentation. ${ }^{66}$ On the other hand, she could probably state that they have received another offer and suggest to the $\$ 42$ million bidder that it will cost $\$ 50$ million to purchase the business. When this statement is made, the lawyer is not disclosing the actual value of the other offer. She is truthfully indicating that they have received another offer, and engaging in mere puffery when she indicates that it will take $\$ 50$ million to purchase her client's firm. Since the latter point clearly concerns the settlement intention of her client, it is nonmaterial information within the meaning of the Comment 2 exclusion. What could she ethically say if the other party directly asks her if they have received a $\$ 50$ million offer from the other party? She may not answer this inquiry affirmatively, because they have not received such an offer, and such a misrepresentation would concern material fact. She could, however, indicate that such information is confidential and reiterate that it will take $\$ 50$ million to purchase her client's business.

Does it matter whether attorney misrepresentations regarding client values and settlement intentions are conveyed to lawyers representing other clients as opposed to judicial mediators or private mediators? In 1993, the American Bar Association indicated that knowing misrepresentations regarding client values and settlement intentions made to judicial mediators would be impermissible, based upon the view that the Comment 2

${ }^{66}$ See Kabatchnick v. Hanover-Elm Building Corp., 328 Mass. 341, 103 N.E.2d 692 (1952) (actionable fraud for real estate owner to tell lessee he had an offer from a third party for an exaggerated rental amount in an effort to induce the lessee to enter into a new lease at an unwarranted rental rate). See generally Perschbacher, supra Note , at 90, 127-29; Anne M. Burr, Ethics in Negotiation: Does Getting to Yes Require Candor? 17 NEG. J. 8, 10-11 (2001); G. Richard Shell, Bargaining With the Devil Without Losing Your Soul in WHAT'S FAIR: ETHICS FOR NEGOTIATORS 57, 58-65 (Carrie Menkel-Meadow \& Michael Wheeler, eds., 2004). 
exception only applies to bargaining interactions with opposing counsel. ${ }^{67}$ Since such misstatements to judicial officials would not be confined to adversarial interactions, they would contravene Rule 4.1.

In 2006, the American Bar Association had to decide whether the logic of Formal Opin. 93-370 barred misrepresentations regarding client values and settlement intentions to nonjudicial mediators. ${ }^{68}$ If it followed the reasoning of its 1993 opinion, it would have had to decide that lawyers could not misstate client values and settlement intentions to any neutral parties, but it felt uncomfortable with such an expansive prohibition. As a result, it decided to limit the coverage of the prior opinion to judicial offers, and it held that such conversations with judicial facilitators are governed by Model Rule 3.3(a)(1) ${ }^{69}$ which forbids lawyers from knowingly making false statements of material fact to tribunals. It then indicated that Comment 2 to Rule 4.1 would apply to communications between advocates and nonjudicial mediators, allowing parties to engage in traditional puffing and embellishment in such settings. I agree with this ruling, since when I function as a nonjudicial mediator, the parties regularly misrepresent their client values and settlement intentions during both our joint and separate caucus sessions.

\section{B. Misleading Partial Disclosures}

Negotiators often use selective disclosures to enhance their positions. They discuss the legal doctrines and factual information beneficial to their situations and withhold the circumstances that are not helpful. In most instances, these selective

67 ABA Formal Opin. 93-370 (1993).

68 ABA Formal Opin. 06-439 (2006).

69 See MORGAN \& ROTUNDA, supr Note 20, at 79. 
disclosures are expected by opponents and are considered an inherent aspect of bargaining interactions. When attorneys emphasize their strengths, opposing counsel must work to ascertain their hidden weaknesses. Probing questions can be effectively employed to explore areas not being discussed.

There are times when the partial disclosure of information is improper, because of legal obligations requiring full disclosure. For example, securities regulations generally require stock and bond sellers to disclose certain information to prospective purchasers. The housing laws in many states require sellers to disclose serious defects even if they are not asked about such circumstances. When such affirmative obligations are imposed, attorneys are obliged to disclose the requisite information or expose their clients to liability.

Under some circumstances, partial statements may mislead opposing counsel as effectively as overt misrepresentations. For example, the plaintiff in Spaulding $v$. Zimmerman $^{70}$ sustained cracked ribs and fractured clavicles in an automobile accident. After the ribs and clavicles had healed, the defense attorney had the plaintiff examined by his own medical expert who found an aorta aneurysm that neither the claimant nor his attorney knew about. Although the defense lawyer was under no ethical obligation to voluntarily disclose the existence of the aneurysm and could ignore questions regarding the independent medical examiner's findings, he could certainly not overtly misrepresent the doctor's diagnosis. Would it be ethical for the defense counsel to respond to plaintiff attorney questions regarding this matter by stating that "the ribs and the clavicles have healed"? Would such a partial disclosure constitute a deliberate misrepresentation of

70263 Minn. 346, 116 N.W.2d 704 (1962). 
material fact due to the fact the defendant lawyer realized that the claimant's attorney would interpret such a statement as an indication that everything had healed? Comment 1 to Rule 4.1 expressly addresses this issue when it indicates that "[m]isrepresentations can also occur by partially true but misleading statements ... that are the equivalent of affirmative false statements." ${ }^{, 71}$ Although defense counsel could most likely say nothing about the aneurysm, he could not provide a statement that, while true, is clearly misleading to the claimant's attorney. ${ }^{72}$ Lawyers must thus forego statements that are facially true, but which they know are misleading to listeners who do not appreciate the inherent deception involved.

\section{Nondisclosure of Information}

Although Model Rule 4.1 requires attorneys to be truthful when they make representations concerning material law or fact, Comment 1 indicates that lawyers have "no affirmative duty to inform an opposing party of relevant facts." ${ }^{, 73}$ In the absence of special relations imposing fiduciary relationships or express contractual or statutory duties, practitioners are normally not obligated to divulge relevant legal or factual

${ }^{71}$ See generally Donald C. Langevoort, Half-Truths: Protecting Mistaken Inferences by Investors and Others, 52 STAN. L. REV. 87 (1999).

${ }^{72}$ It is interesting to note that the American Bar Association recently amended Model Rule 1.6, governing the voluntary disclosure of confidential client information, to permit - but not require - disclosure of the type of information involved in the Spaulding case where the lawyer reasonably believes that such disclosure is "necessary to prevent reasonably certain death or substantial bodily harm." See MORGAN \& ROTUNDA supra Note 20, at 22.

${ }^{73}$ MORGAN \& ROTUNDA, supra Note 20, at 93. 
information to their opponents. ${ }^{74}$ This doctrine is premised upon the duty imposed upon representatives to conduct their own legal research and factual investigations. Under our adversary system, lawyers do not have the right to expect their opponents to assist them in this regard. ${ }^{75}$ It is only when cases reach tribunals that Model Rule 3.3(a)(2) imposes an affirmative obligation on advocates "to disclose to the tribunal legal authority in the controlling jurisdiction known to the lawyer to be directly adverse to the position of the client and not disclosed by opposing counsel." ${ }^{76}$ It is interesting to note that no such duty is imposed upon litigants by Rule 3.3(a)(2) with respect to pertinent factual circumstances that may favor the other side which have not been discovered by opposing counsel.

Stare v. Tate $^{77}$ involved divorce negotiations designed to divide the spouses' community property on an equal basis. When valuing certain property, Ms. Stare's attorney made a mathematical error that understated the actual value by $\$ 100,000$. Although Mr. Tate and his lawyer were aware of this miscalculation, they said nothing and agreed to settlement terms that deprived Ms. Stare of $\$ 50,000$. Since Mr. Tate and his

${ }^{74}$ See Barry R. Temkin, Misrepresentation by Omission in Settlement Negotiations: Should There Be a Silent Safe Harbor? 18 GEO. J. LEGAL ETHICS 179 (2004); Robert McKay, Ethical Considerations in Alternative Dispute Resolution, 45 ARB. J. 15, 19 (March 1990); Thomas F. Guernsey, Truthfulness in Negotiation, 17 U. RICH. L. REV. 99, 116 (1982-83); Deborah A. DeMott, Do you Have the Right to Remain Silent? Duties of Disclosure in Business Transactions, 19 DEL. J. CORP. L. 65 (1994). See also Alan Strudler, Moral Complexity in the Law of Nondisclosure, 45 U.C.L.A. L. REV. 337 (1997).

${ }^{75}$ See Hazard, supra Note 22, at 185-86.

${ }^{76}$ MORGAN \& ROTUNDA, supra Note 20, at 79.

7721 Cal.App.3d 432, 98 Cal. Rptr. 264 (1971). 
attorney were fully aware of Ms. Stare's miscalculation and sought to take advantage of it, the court reformed the property settlement to provide Ms. Stare with the additional $\$ 50,000$ she deserved.

Stare v. Tate should be compared with Brown v. County of Genesee ${ }^{78}$ which concerned a county attorney who was negotiating the resolution of a Rehabilitation Act claim with the lawyer representing a diabetic employee. The claimant attorney made a proposal to place the employee on a certain salary level which they believed to be the highest she could attain, when she could actually have been placed at a higher level. The court found that the county attorney had no legal or ethical duty to correct their erroneous belief in this regard, since the mistake by the claimant and her counsel was due to their failure to examine or understand the public records available to everyone, and her counsel could have requested this information. The court thus refused to modify the claimant's settlement agreement to allow her to receive the higher salary, because the mistaken belief was unilateral, rather than mutual. Should the county attorney, as a public official, have been under an affirmative duty to correct the claimant's obvious misunderstanding, or should the conventional rule of caveat emptor applicable to private sector negotiators have been controlling? May the Brown determination be distinguished from the holding in Stare v. Tate, based upon the fact Stare involved a wholly private issue while Brown involved a public record that anyone could have checked?

Suppose attorneys representing a severely injured plaintiff learn, during the critical stages of settlement discussions, that their client has died due to factors unrelated to the underlying law suit. Would they be under an ethical duty to disclose this fact to

78872 F.2d 169 (6 (th $^{\text {Cir. } 1989) . ~}$ 
defense counsel who are clearly assuming continuing pain and medical care for the plaintiff? In Virzi v. Grand Trunk Warehouse \& Cold Storage,${ }^{79}$ the court held that the claimant's counsel had a clear duty to disclose the death of his client both to the court and to opposing counsel prior to the negotiation of a settlement agreement. Since the death of the claimant would presumably have necessitated the substitution of plaintiff's estate executor, plaintiff counsel should have been obliged to notify defense attorneys of the plaintiff's demise before any agreement was concluded that affected the claimant's estate ${ }^{80}$ Furthermore, assuming plaintiff attorneys had provided defense counsel with answers to interrogatories concerning the medical condition of their client during the discovery process, they would have been under a duty to correct these answers once the claimant's condition had become fatal. ${ }^{81}$

Suppose the party possessing the relevant medical information regarding a plaintiff is not the plaintiff's attorney, but rather the defense counsel? This issue was directly raised in Spaulding v. Zimmerman ${ }^{82}$ which was mentioned previously. Spaulding's ribs and clavicles, which had been fractured in an automobile accident, had

${ }^{79} 571$ F. Supp. 507 (E.D. Mich. 1983).

${ }^{80}$ Cf. Kentucky Bar Assn. v. Geisler, 938 S.W.2d 578 (Ky. Sup. Ct. 1997) (sustaining public reprimand for plainfiff attorney who failed to notify defense counsel that plaintiff had died during their settlement negotiations). See also A.B.A. Formal Opinion 95-397 (1995) (indicating that lawyer's failure to disclose the death of his client was tantamount to making a false statement of material fact in violation of Model Rule 4.1).

${ }^{81}$ Fed. Rule of Civ. Pro. 26(e)(2) provides that "[a] party is under a duty seasonably to amend a prior response to an interrogatory, request for production, or request for admission if the party learns that the response is in some material respect incomplete or incorrect and if the additional or corrective information has not otherwise been made known to the other parties during the discovery process or in writing."

${ }^{82} 263$ Minn. 346, 116 N.W.2d 704 (1962). 
healed, and he seemed to be well on the road to recovery. The physician who conducted an independent medical examination for the defense attorneys discovered an aneurysm on Spaulding's aorta. Defense counsel was never asked by plaintiff counsel about the results of this examination, and he did not volunteer any information regarding the physician's findings.

A settlement agreement was achieved, which had to be approved by the trial judge, since David Spaulding was a minor. After the case was settled, Spaulding's condition was discovered during a military induction physical, and the aneurysm was surgically repaired. He discovered that the defense counsel was aware of this condition, and he moved to set aside the prior settlement agreement. The trial judge vacated the agreement, and the case was appealed to the Minnesota Supreme Court. Despite the fact that most people would undoubtedly regard an affirmative duty to disclose the critical medical information to be the morally appropriate approach, ${ }^{83}$ the Minnesota Supreme Court correctly determined that the defense attorneys were under no ethical duty to volunteer the discovered aneurysm to plaintiff counsel. In fact, without client consent, the confidentiality preservation obligation then imposed by Model Rule 1.6 precluded voluntary disclosure by defense counsel under these circumstances. Comment 5 expressly stated that " $[\mathrm{t}]$ he confidentiality rule ... applies not merely to matters communicated in

\footnotetext{
${ }^{83}$ These persons would probably expect the examining physician to be under a similar duty to disclose the aneurysm pursuant to the Hippocratic Oath. Even though the doctor was not a treating physician but only an expert witness retained by the defense counsel, their obligation to do no harm should oblige him to disclose such a life-threatening condition even if he is not treating the person being examined.
} 
confidence by the client but also to all information relating to the representation, whatever its source." ${ }^{\prime 84}$

The Spaulding Court circumvented the Rule 1.6 prohibition by holding that as officers of the court, defense counsel had an affirmative duty under Rule $3.3(a)(1)^{85}$ to disclose the newly discovered medical information to the trail judge prior to his approval of the settlement agreement. Had Spaulding not been a minor, the Court may have been obliged to enforce the original accord, because of the absence of any trial court involvement in the settlement process.

If courts are unwilling to impose affirmative disclosure obligations on advocates who possess such critical information pertaining to opposing clients, they should sustain the resulting settlement agreements despite the lack of disclosure. This would at least permit defense lawyers to divulge the crucial information as soon as the settlement terms have been satisfied. By voiding such agreements after plaintiffs learn of the withheld information, judges effectively require defense counsel to remain silent even after law suits have been finally resolved.

The Restatement $\left(3^{\text {rd }}\right)$ of the Law Governing Lawyers protects defense attorneys who divulge medical information in Spaulding-type situations. Section 66 indicates that attorneys who voluntarily disclose information concerning a condition posing a reasonably certain risk of death or serious bodily injury to opposing counsel should not

\footnotetext{
${ }^{84}$ THOMAS D. MORGAN \& RONALD D. ROTUNDA, 2004 SELECTED STANDARDS ON PROFESSIONAL RESPONSIBILITY 179-180 (Foundation Press 2004). The same language is now found in Comment 3 , see MORGAN \& ROTUNDA, supra Note 20, at 23, but its impact has been modified by the change in Rule 1.6 discussed below.

${ }^{85}$ See MORGAN \& ROTUNDA, supra Note 20, at 79.
} 
be found in violation of Rule 1.6 nor be subject to legal malpractice liability to their own clients. ${ }^{86}$ In 2003, the ABA House of Delegates amended Model Rule 1.6 to comport with Section 66 of the Restatement. Rule 1.6(b)(1) now permits - but does not require attorneys to disclose otherwise confidential information when necessary "to prevent reasonably certain death or substantial bodily harm." ${ }^{, 7}$

Suppose plaintiff or defense counsel are on the verge of a law suit settlement based upon a line of State Supreme Court cases favoring their client. The morning of the day they are scheduled to finalize their transaction, the State Supreme Court issues an opinion overturning the prior beneficial decisions and indicating that the new rule applies to all pending cases. Would knowledgeable attorneys whose position has been completely undermined by these legal changes be obligated to inform their unsuspecting opponents about this critical development before the settlement agreement is executed? Most practitioners I ask respond in the negative, based on their belief that legal counsel are obliged to conduct their own legal research. They could not, however, continue to cite the decisions that have been overruled, because such legal misstatements would contravene Rule 4.1.

Suppose that settlement talks have been continuing while a defense motion for summary judgment has been pending before the trial court. One morning, the claimant attorney receives a court order in the mail indicating that the defendant's motion for summary judgment had been granted. The plaintiff lawyer telephones the defense counsel

\footnotetext{
${ }^{86}$ See THE AMERICAN LAW INSTITUTE, RESTATEMENT OF THE LAW THIRD: THE LAW GOVERNING LAWYERS 496 (2000).
}

${ }^{87}$ MORGAN \& ROTUNDA, supra Note 20, at 22. See 72 U.S. LAW WEEK (No. 6) 2091 (Aug. 19, 2003). 
and realizes that she has not yet received notice of her summary judgment victory. Could plaintiff counsel try to settle the case immediately without disclosing this fact? No Model Rule appears to answer this question, and a few attorneys have told me that they would have no hesitancy to seek a final accord without disclosure. Most lawyers, however, believe that as officers of the court they would be under an affirmative duty to notify defense counsel of the court's communication since such a notice is expected to reach both sides simultaneously. A number of judges I have asked have unanimously agreed with the latter view, suggesting that they would vacate any settlement achieved by plaintiff counsel without disclosure.

\section{Deception by Disingenuous Conduct}

Suppose two parties are negotiating and one provides the other with a written proposal. The recipient of the proposal looks disappointed, tears up the written document, and walks out of the room. If the terms set forth in the proposal are actually within the settlement range of the recipient, would that person's actions be unethical since designed to mislead the offeror? Most legal practitioners would answer in the negative, on the ground the misleading demonstrative behavior concerns their underlying settlement intentions that are considered nonmaterial fact information under Comment 2 to Rule 4.1. Such threats or bluffs are part of many bargaining interactions. They may hinder effective integrative negotiations, but they may be effectively employed by individuals seeking to claim value for themselves. ${ }^{88}$ Only communitarian-oriented theorists who believe that no

88 See generally Debra L. Shapiro \& Robert J. Bies, Threats, Bluffs, and Disclaimers in Negotiations, 60 ORGANIZATIONAL BEHAVIOR \& HUMAN DEC. PROCESSES 14 (1994). 
deceitful conduct should be permitted during bargaining interactions would be likely to consider such actions to be improper. ${ }^{89}$

\section{E. Unintended Access to Confidential Opponent Information}

When attorneys provide documents pursuant to discovery requests or send negotiation proposals to opposing counsel, they occasionally include confidential or privileged client documents they did not intend to include. What should opposing counsel do when the realize that they have received documents they were not supposed to see? Model Rule 4.4(b) states that "[a] lawyer who receives a document relating to the representation of the lawyer's client and knows or reasonably should know that the document was inadvertently sent shall promptly notify the sender."90

Before or after receiving attorneys notify opposing counsel of their receipt of documents not intended for their viewing, may they examine those papers? Neither Rule 4.4(b) nor the Comments following that Rule answer this question. "Whether the lawyer is required to take additional steps, such as returning the original document, is a matter of law beyond the scope of these Rules, as is whether the privileged status of a document has been waived." 91

Some lawyers may choose to return a document unread, for example, when the lawyer learns before receiving the document that it was inadvertently sent to the wrong address. Where a lawyer is not required by applicable law to do so, the decision to voluntarily return such a document is a matter of professional judgment ordinarily reserved to the lawyer. ${ }^{92}$

89 See Reed Elizabeth Loder, Moral Truthseeking and the Virtuous Negotiator, 8 GEO. J. LEGAL ETHICS 45, 79-81 (1994-95).

${ }^{90}$ MORGAN \& ROTUNDA, supra Note 20, at 97.

${ }^{91}$ Comment 2, MORGAN \& ROTUNDA, supra Note 20, at 97.

${ }^{92}$ Comment 3, MORGAN \& ROTUNDA, supra Note 20, at 97. 
I do not believe that the ABA should provide such ambiguous and unhelpful guidance. In ABA Formal Opinion 92-368 (1992), the ABA indicated that attorneys who receive confidential or privileged materials from opposing counsel that appear to have been sent to them inadvertently should refrain from examining those materials. They were directed to notify opposing counsel of the circumstances and abide by the instructions provided by those persons. Current Rule 4.4(b) continues to require attorneys who obtain confidential or privileged information that seems to have been inadvertently sent by opposing counsel to notify those lawyers, but the receiving attorneys are no longer obliged to refrain from examining those documents nor must they abide by the instructions they receive from the sending lawyers.

I believe that the modified Rule 4.4(b) pessimistically assumes that most legal representatives are dishonorable persons who will not voluntarily refrain from taking advantage of erroneous disclosures of confidential or privileged information by opposing attorneys. It thus inexplicably allows recipients of mistakenly sent information to peruse those materials. I think that most attorneys are honest persons who would not take undue advantage of such errors by other lawyers. As soon as it becomes clear that they have received documents not intended for their viewing, the vast majority would be willing to refrain from any further examination of those materials. They would immediately notify opposing counsel of their apparent mistake and abide by the instructions they receive from those individuals. The recipients might be told to return the documents unread, or to destroy them without further examination. The fact that a few attorneys would take undue 
advantage of such errors by opposing counsel should not dictate the obligations that should be imposed on honorable lawyers.

A somewhat related issue arises with respect to e-mail communications exchanged by legal representatives. When people send Word or WordPerfect files, the electronic files contain metadata which recipients can access. This allows the recipients of such electronic files to ascertain every change made in those files since their creation. Attorneys drafting demand letters or other position statements may make numerous modifications which demonstrate the degree to which they have altered their positions. For example, plaintiff attorneys may increase or decrease the amount of money they are claiming for their clients, or defense lawyers may inadvertently disclose weaknesses in their positions. When I talk to legal practitioners about the ability of others to mine the metadata contained in the electronic files they send, the overwhelming majority are shocked. They have no idea what I am talking about.

Legal representatives who receive electronic files from other attorneys should recognize the fact that most of the senders are unaware of the metadata contained in those files. If they were aware of these metadata, they would take precautions to eliminate them. The senders expect the recipients to open the files and see exactly what the ssenders could see on their computer monitors or on the printed versions of those files. They do not expect the file recipients to ascertain the changes they have made in those files. In ABA Formal Opinion 06-442 (2006), the ABA ignored this fact and indicated that lawyers have no ethical obligation to refrain from mining and using the metadata embedded in electronic files received from other attorneys. Although Comment 2 to Rule 4.4 indicates that the term “'document' includes e-mail or other electronic modes of 
transmission subject to being read or put into readable form," 93 the most the recipients of such files must do is notify the senders of their mistake. They do not have to refrain from mining the metadata, nor do they have to abide by any instructions they may receive from the transmitting attorneys. ${ }^{94}$

The New York Bar, ${ }^{95}$ the Alabama Bar, ${ }^{96}$ and the Maine Bar $^{97}$ have indicated that such mining of metadata in electronic files contravenes Model Rule 8.4 which states that it constitutes "professional misconduct" for a lawyer to "engage in conduct involving dishonesty, fraud, deceit or misrepresentation [or] . . . that is prejudicial to the administration of justice." 98 The Alabama Bar acknowledged that the "mining of metadata constitutes a knowing and deliberate attempt by the recipient attorney to acquire confidential and privileged information in order to obtain an unfair advantage against an opposing party."

I agree with the New York, Alabama, and Maine Bar Associations. Attorneys who receive electronic files should only be permitted to open those files to see what the sending lawyers intended them to see. It should be entirely unethical for them to mine the metadata they know the senders did not realize they had included in their electronic files.

${ }^{93}$ MORGAN \& ROTUNDA, supra Note 20, at 97.

94 A similar conclusion was reached by the Maryland Bar Ethics Committee [Md. Bar Ethics Opin. 2007-09], but the Maryland Committee emphasized the fact that the Maryland Bar has not adopted Model Rule 4.4(b).

95 N.Y. State Bar Ethics Opin. 749 (2001).

96 Ala. State Bar Disciplinary Comm. Opin. 2007-02 (2007).

97 Me. Bd. of Bar Overseers Professional Ethics Comm. Opin. 196 (10/21/08).

${ }^{98}$ MORGAN \& ROTUNDA, supra Note 20, at 128. 
The recipients should not have to notify the senders of their inadvertent inclusion of those metadata, because they should not be looking for those metadata.

All state bar associations should advise attorneys practicing in their jurisdictions about the presence of metadata in electronic files. The New York Bar, ${ }^{99}$ the Alabama Bar, ${ }^{100}$ and the Maine Bar $^{101}$ have concluded that attorneys have an ethical obligation under the confidentiality duty imposed by Model Rule 1.6 to use "reasonable care" when transmitting electronic documents to prevent the inclusion of metadata containing confidential or privileged client information. There are several ways lawyers sending electronic files can preclude the unintended transmission of such metadata. They can use a scrubbing software program designed to eliminate the metadata from files before they are sent to opposing counsel. They can alternatively create new files and then insert the existing files into the newly created files. This insertion option eliminates the metadata contained in the existing files that were inserted into the newly created files. At a minimum, they should only transmit PDF files which minimize the metadata contained in them.

\section{INAPPROPRIATE TACTICS AND UNCONSCIONABLE AGREEMENTS}

In recent years, an increasing number of legal representatives - especially in larger urban areas - have decided to employ offensive negotiation tactics to advance client interests. They behave in a rude, sarcastic, or nasty manner. I have even noticed an increase in such behavior by students in my Legal Negotiation course. Such actors

\footnotetext{
${ }^{99}$ N.Y. State Ethics Opin. 782 (2004).

100 Ala. State Bar Disciplinary Comm. Opin. 2007-02 (2007).

101 Me. Bd. of Bar Overseers Professional Ethics Comm. Opin. 196 (10/21/08).
} 
erroneously equate discourteous behavior with effective advocacy. They use these techniques as a substitute for negotiation proficiency. Capable negotiators recognize the fact that discourteous behavior is the least effective means of inducing competent opponents to give in to bargaining requests. ${ }^{102}$

Lawyers should never employ tactics that are merely intended to humiliate or harass opponents. Model Rule 4.4(a) provides that "a lawyer shall not use means that have no substantial purpose other than to embarrass, delay, or burden third persons . . " ${ }^{\prime 103}$ Highly competitive win-lose negotiators may seek to achieve the complete annihilation of adversaries through rude and degrading conduct. Although such behavior may induce a few unskilled and timid persons to concede more than they should, proficient bargainers would not allow such tactics to weaken their resolve. In fact, such conduct would be likely to have the opposite effect. They would refuse to move to avoid exploitation by such unprofessional opponents.

Uncivil and unprofessional conduct is not only morally reprehensible, but it also exposes the offensive actors to future recriminations that could subvert their future bargaining encounters. Persons offended by rude tactics would work to deny such individuals what they wanted to achieve in future interactions, and they would inform their colleagues of the unprofessional nature of their approach. Persons who know of the negative reputations of hard bargainers would thoroughly prepare for negotiations with such actors, and would work to deny those persons the concessions they seek to obtain

102 See Jonathan R. Cohen, The Ethics of Respect in Negotiation, 18 NEG. J. 115, 118 (2002).

${ }^{103}$ MORGAN \& ROTUNDA, supra Note 20, at 96. 
through openly intimidating behavior. Legal negotiators need to recall the sagacious advice they received from parents during their formative years: "You get far more with honey than with vinegar!"104

When attorneys use personally offensive tactics to harass or intimidate opponents, their behavior should be found to violate Rule 4.4(a). Such conduct really has no purpose other than to "burden third persons." If bar associations were to believe that the general language of Rule 4.4(a) does not clearly cover such rude actions, they should consider amendments to make it unequivocally clear that nasty and personally insulting behavior is unprofessional and unethical. If a few highly offensive practitioners were disciplined for wholly unacceptable conduct, bar members contemplating such actions would be deterred, and other attorneys would find practice more pleasant.

Many negotiations are conducted through telephone conversations. In the near future, such interactions will be conducted by video phones via Internet connections. Since most individuals do not hear all of the words spoken during these discussions - and would undoubtedly miss many nonverbal signals emanating from opposing counsel they may be tempted to secretly record their bargaining conversations to enable them to review those interactions carefully once they have ended. Would such behavior be ethical? Although federal law does not prohibit the secret taping of telephone calls by one of the participants without the other party's knowledge, some state laws make such conduct illegal. In those jurisdictions, it would clearly be improper for lawyers to secretly tape telephone conversations with other attorneys.

104 See Jonathan R. Cohen, The Ethics of Respect in Negotiation in WHAT'S FAIR: ETHICS FOR NEGOTIATORS 257, 260 (Carrie Menkel-Meadow \& Michael Wheeler, eds., 2004). 
In states where it is not unlawful for one party to secretly tape phone conversations with others, would it be ethical for negotiating lawyers to tape discussions with opposing counsel? Some state bar associations have indicated that where secret taping is not proscribed, attorneys do not behave unethically when they engage in such behavior. ${ }^{105}$ Other state bar associations, however, have reached the opposite conclusion, believing that attorneys conducting telephone interactions with other lawyers have the right to expect those discussions to remain untapped without the knowledge and consent of both participants. I agree with this perspective. When legal representatives interact by telephone or even in person - they should not fear that their conversations are being taped for future examination by opposing counsel unless they have expressly agreed to such an approach.

Proposed Rule 4.3 of the Discussion Draft of the ABA Model Rules would have precluded attorneys from concluding agreements "the lawyer knows or reasonably should know ... would be held to be unconscionable as a matter of law ..."106 This provision would have codified that admonition of Judge Alvin Rubin to avoid the negotiation of "unconscionable deals." 107 This provision was omitted from the final draft, most likely because of its superfluous nature. If bargained agreements are "unconscionable as a matter of law," they are subject to legal challenges that may negate their enforceability. It

105 See J. Pitulla, The Ethics of Secretly Taping Phone Conversations, ABA J. 102 (Feb. 1994).

106 See Lowenthal, supra Note 19 at 103.

107 See Rubin, supra Note 2, at 591, and accompanying text. 
thus behooves legal representatives to avoid the consummation of truly unconscionable accords.

What about seemingly one-sided arrangements that have not been procured through improper means and that do not constitute legally unconscionable agreements. Should it be considered unethical or morally reprehensible for attorneys to obtain such contracts? Such a concept would place the responsible lawyers in a tenuous position. If courts would be unlikely to find the resulting accords unlawful and the opposing parties were perfectly willing to enter into the apparently skewed arrangements, should the prevailing legal representatives refuse to consummate the deals simply because they think they may unreasonably disadvantage their opponents $?^{108}$ Why should the subjective personal judgments of these sanctimonious lawyers take precedence over the willingness of opposing parties to effectuate the proposed exchanges - and the right of their own clients to obtain the benefits of the bargains that have been struck? ${ }^{109}$ These individuals may not know - and may never know - why their opponents found these deals acceptable. Their adversaries may have been aware of factual or legal circumstances that either undermined their own positions or bolstered those of the other side.

Picture the situation where the claimant attorney believes that $\$ 500,000$ would constitute a "fair" resolution of the underlying dispute. During the bargaining

108 See generally John Richardson, How Negotiators Choose Standards of Fairness: A Look at Empirical Evidence and Some Steps Toward a Process Model, 12 HARV. NEG. L. REV . 415 (2007); Cecilia Albin, The Role of Fairness in Negotiation, 9 NEG. J. 223 (1993).

109 "Lawyers' personal moral beliefs . . . should not be interposed between the client and the client's otherwise lawful objectives." W. Bradley Wendel, Public Values and Professional Responsibility, 75 NOTRE DAME L. REV. 1, 52 (1999). See Norton, supra Note 23, at 552-556. 
discussions, it becomes clear that the opposing lawyer thinks the plaintiff deserves more. She offers $\$ 850,000$. The claimant representative contacts his client and indicates that the defendant offered $\$ 850,000$, but he decided to accept $\$ 500,000$ due to his belief that the $\$ 850,000$ figure is "excessive." I could not image many clients who would be satisfied with such a conclusion. At a minimum, the lawyer would be under an obligation under Model Rule 1.4 to promptly inform his client of the defendant's offer, ${ }^{110}$ and Model Rule 1.2(a) would require him to "abide by [his] client's decision whether to settle [the] matter." ${ }^{111}$ I could easily imagine a legal malpractice suit brought by such a client against the responsible attorney who decided to forego the $\$ 850,000$ offer in favor of the "more reasonable" $\$ 500,000$ figure. It would certainly be appropriate for such an attorney to suggest to his client that the $\$ 850,000$ offer seems excessive, but if the client decides to accept the higher figure, I think the lawyer would be obliged to follow the client's instructions. ${ }^{112}$

Once negotiators achieve final agreements, one side usually drafts the actual terms. If an attorney were to deliberately change a term or delete something that was agreed upon, the client could be held liable for fraud and the legal representative would be subject to discipline. ${ }^{113}$ Negotiators have a clear duty to prepare documents that

${ }^{110}$ Comment 2 to Rule 1.4 explicitly imposes this obligation on attorneys negotiating on behalf of clients. See MORGAN \& ROTUNDA, supra Note 20, at 17.

${ }^{111} I d$. at 12.

112 See Stephen L. Pepper, A Lawyer's Amoral Ethical Role: A Defense, a Problem, and Some Possibilities, 1986 AMER. BAR FOUND. RES. J. 613, 616 (1986): "When the client's interest and the professional's interest conflict, the processional is to forgo his interest in favor of the client's."

${ }^{113}$ See, e.g., Crane v. State Bar, 30 Cal.3d 117, 635 P.2d 163 (1981). 
represent the terms the parties intended to constitute their accord. Suppose one side prepares the agreement, and the opposing party realizes that the drafter has inadvertently omitted a provision agreed upon? Although no Model Rule explicitly addresses this situation, ABA Formal Opinion 86-1518 (1986) indicated that the party aware of the omission should contact the drafting attorney to correct the omission.

Suppose the attorney representing Side B in a negotiation believes the Side A has agreed to pay Side B \$28 million. When she receives the draft agreement from Side A, the document indicates that Side A is to pay Side B $\$ 30$ million. Would the Side B legal representative be under an obligation to notify the Side A lawyer of this apparent mistake? I think the answer is yes, but I think she should do so carefully. During the rush to conclude bargaining interactions, parties often exchange terms quickly. It is possible that Side A actually suggested the $\$ 30$ million figure in exchange for some final concessions being made by Side B. She should thus contact the Side A representative and indicate that she cannot recall the precise amount agreed upon. If the Side A lawyer affirms the $\$ 30$ million figure, she should accept this representation. On the other hand, if the Side A representative realizes his mistake and suggests that \$28 million was the amount actually intended, the Side B lawyer should accept the correction. ${ }^{114}$

May attorneys who represent clients in civil actions arising out of arguably criminal conduct (e.g., a sexual harassment lawsuit arising from physical conduct by the

114 But cf. Los Angeles County Bar Assn Professional Responsibility \& Ethics Committee Opin. 520 (2007) (indicating that attorney who realizes client mistakenly received settlement over-payment may not unilaterally notify opposing counsel but must instead apprise client of error and abide by client's decision whether or not to disclose mistake). 76 U.S. LAW WEEK (No. 10) 2148 (Sept. 18, 2007). 
defendant) suggest the possibility of criminal charges being filed if the civil suit negotiations are not resolved in a satisfactory manner? DR 7-105(A) of the ABA Code of Professional Responsibility, which is still followed by a few jurisdictions, states that lawyers "shall not present, participate in presenting, or threaten to present criminal charges solely to obtain an advantage in a civil matter." "115 This provision might be read to prevent the mention of possible criminal prosecution to advance civil suit negotiations. Nonetheless, courts have acknowledged that neither DR 7-105(A), nor laws proscribing extortion or compounding of felonies, should be interpreted to prevent civil litigants from mentioning the possibility of criminal action if related civil claims are not resolved or to preclude clients from agreeing to forego the filing of criminal charges in exchange for compensation to be paid to resolve the civil matters. ${ }^{116}$ Legal representatives must be careful, however, not to use the threat of criminal prosecution to obtain more than is owed to their clients or have their clients agree not to testify at future criminal trials. "Seeking payment beyond restitution in exchange for foregoing criminal prosecution or seeking any payments in exchange for not testifying at a criminal trial . . . are still clearly prohibited. ${ }^{, 117}$ In a similar case, the Oregon Supreme Court held that it was unethical for an attorney to threaten the possibility of criminal charges solely to obtain an advantage regarding negotiations pertaining to a related civil matter. ${ }^{118}$ A threat to invoke criminal

115 MORGAN \& ROTUNDA, supra Note 20, at 243.

116 See, e.g., Committee on Legal Ethics v. Printz, 187 W. Va. 182, 416 S.E.2d 720 (1992).

117416 S.E.2d at 727.

${ }^{118}$ In re Charles, 290 Or. 127, 618 P.2d 1281 (1980). 
charges to enhance one's position in an unrelated civil dispute would almost certainly be improper, because of the extortionate nature of such a threat. ${ }^{119}$

The Model Rules do not contain any provision analogous to DR 7-105(A), and it is clear that the drafters intentionally chose not to prohibit the threat of criminal action to advance civil suit settlement discussions pertaining to the same operative circumstances. ${ }^{120}$ As a result, the ABA Standing Committee on Ethics and Professional Responsibility indicated in ABA Formal Opinion 92-363 (1992) that it is not unethical under the Model Rules for attorneys to mention the possibility of criminal charges during civil suit negotiations, so long as they do "not attempt to exert or suggest improper influence over the criminal process." ${ }^{, 21}$ Nevertheless, legal representatives must still not demand excessive compensation that may contravene applicable extortion statutes or promise that their clients will not testify at future criminal trials, since such a commitment would contravene public policy.

\section{ETHICAL ISSUES PERTAINING TO COLLABORATIVE LAW AND COOPERATIVE LAW ARRANGEMENTS}

The Collaborative Law movement began in the early 1990s by family law practitioners who wanted to decrease the adversarial nature of their bargaining interactions. ${ }^{122}$ Family law disputes often involve highly emotional issues that

119 See Bluestein v. State Bar, 13 Cal.3d 162, 529 P.2d 599 (1974).

${ }^{120}$ See Pitulla, supra Note 105, at 106.

${ }^{121} I d$.

122 See Scott R. Peppet, The Ethics of Collaborative Law, 2008 J. DISP. RES. 131, $132-$ 33 (2008). See generally NANCY J. CAMERON, COLLABORATIVE PRACTICE: DEEPENING THE DIALOGUE (2004); SHEILA M. GUTTERMAN, 
significantly affect divorcing spouses - and their children. Many attorneys specializing in this area have functioned in a tough and competitive manner. As family law practitioners began to appreciate the fact that this adversarial approach generated negative consequences both for themselves and their clients, a number of innovative lawyers decided to develop a more open and cooperative style based upon the Getting to Yes model.

Family law practitioners and their clients execute a four-way agreement specifying the cooperative/problem-solving approach they will follow. The participants promise to be completely open and to share all relevant information on a voluntary basis. They will interact in a professional and respectful manner designed to generate mutually beneficial and jointly efficient settlement agreements with a minimum of discomfort to the lawyers and their clients. The legal negotiators will be open and direct, and will never resort to bluffing, puffing, and other value-claiming behavior. The most controversial aspect of their four-way agreements acknowledge that if the current parties are unable to reach a settlement, the lawyers will be disqualified and not be permitted to take the underlying dispute to trial. The clients will have to retain other counsel to carry out that function.

COLLABORATIVE LAW: A NEW MODEL FOR DISPUTE RESOLUTION (2004); KATHERINE E. STONER, DIVORCE WITHOUT COURT: A GUIDE TO MEDIATION AND COLLABORATIVE DIVORCE (2006); PAULINE H. TESLER, COLLABORATIVE LAW: ACHIEVING EFFECTIVE RESOLUTION IN DIVORCE WITHOUT LITIGATION (2001); PAULINE H. TESLER \& PEGGY THOMPSON, COLLABORATIVE DIVORCE: THE REVOLUTIONARY NEW WAY TO RESTRUCTURE YOUR FAMILY, RESOLVE LEGAL ISSUES, AND MOVE ON WITH YOUR LIFE (2006); STUART G. WEBB \& RON D. OUSKY, THE COLLABORATIVE WAY TO DIVORCE: THE REVOLUTIONARY METHOD THAT RESULTS IN LESS STRESS, LOWER COSTS, AND HAPPIER KIDS WITHOUT GOING TO COURT (2006); William H. Schwab, Collaborative Law: A Closer Look at an Emerging Practice 4 PEPP. DISP. RES. L.J. 351 (2004). 
The major ethical issue thus far examined with respect to the propriety of Collaborative Law arrangements has concerned the disqualification provision. The Colorado $\operatorname{Bar}^{123}$ found that the disqualification obligation contravened Model Rule 1.7(a)(2) which forbids an attorney from representing a client if there is a significant risk that the client's representation may be "materially limited by the lawyer's responsibilities to ... a third person," unless (1) the lawyer reasonably believes the representation will not be adversely affected and (2) the client consents to the representation after consultation with the attorney. ${ }^{124}$ The Colorado Bar found that the disqualification provision creates an obligation to third persons - opposing counsel and opposing clients that involves a conflict between the lawyer and his or her client that cannot be cured by mere client consent. On the other hand, the American Bar Association considered the same issue and concluded that the potential conflict was not so insurmountable that a client could not consent to the disqualification provision. ${ }^{125}$

Before client consent should be acceptable, lawyers should be obliged to explain in detail the potential consequences of the disqualification provision. If cases are not resolved amicably, new attorneys will have to be retained, those legal representatives will have to become familiar with all of the relevant case information, and legal costs are likely to increase substantially. While the likelihood of such a result is generally low, especially where the Collaborative Law attorneys are working diligently to avoid the

${ }^{123}$ Colo. Bar Ethics Comm. Opin. 115 (Feb. 24, 2007).

${ }^{124}$ MORGAN \& ROTUNDA, supra Note 20, at 27.

125 A.B.A. Formal Opin. 07-447 (2007). 
need for litigation, clients must appreciate the negative consequences that might arise if mutual arrangements cannot be achieved.

Ethical issues can also arise under Model Rule 1.2(c) which provides that "[a] lawyer may limit the scope of the representation if the limitation is reasonable under the circumstances and the client gives informed consent." ${ }^{126}$ Collaborative Law practitioners have agreed among themselves to avoid many traditional negotiating tactics that might advance their own client interests at the expense of opposing parties. ABA Formal Opinion 07-447 found that the Collaborative Law Agreement limitations did not contravene Rule 1.2 (c), so long as they did not interfere with the concomitant attorney duties of competence and diligence. New Jersey Bar Ethics Opinion $699^{127}$ indicated that lawyers must initially determine whether their commitment to Collaborative Law rules would be "reasonable" under Rule 1.2. The opinion suggested that it would not be "reasonable" for attorneys to require client commitment to their withdrawal where the legal representatives believe there would be a significant possibility the collaborative process would fail and the clients would have to retain the services of replacement attorneys. ${ }^{128}$ After they assess the potential risks associated with the Collaborative Law Rules, attorneys should carefully explain those risks to their clients to be certain that client consent to Collaborative Law representation it truly informed.

To avoid the potential conflict problem associated with disqualification provisions, some legal practitioners developed the Cooperative Law approach which

${ }^{126}$ MORGAN \& ROTUNDA, supra Note 20, at 12.

${ }^{127} 14$ N.J.L. 2474, 182 N.J.L.J. 1055 (2005).

${ }^{128}$ See also Pa. Bar Assn'n Comm. Leg. Ethics \& Prof'1 Respon. Informal Op. 2004-24 (2004). 
follows the Collaborative Law rules, but with one critical exception. Cooperative Law practitioners eliminated the attorney disqualification provision. As a result, if their open and cooperative discussions fail to generate settlement agreements, the originally retained legal representatives may take the cases to trial.

The Collaborative Law movement completely embraces the communitarian law concept. These are individuals who are uncomfortable with the traditional give-and-take of the bargaining process and with the overt or subtle deceit and competition associated with such interactions. Rather than try to diminish rude or unprofessional behavior, while still engaging in true legal negotiating, they have created a wholly artificial world which is impossible to effectively monitor. How can they be certain that Collaborative Law participants are being completely open? How can they be sure no one has embellished their actual bottom line to obtain a bargaining advantage?

It has been suggested that a large proportion of Collaborative Law practitioners are "women in their fifties and sixties who are 'tired of arguing with each other'." ${ }^{29}$ This is consistent with the findings that "women are more likely [than men] to avoid competitive situations, less likely to acknowledge competitive wishes, and not likely to do as well [as men] in competition." ${ }^{130}$ It is also consistent with studies finding

${ }^{129}$ John Lande, Practical Insights From an Empirical Study of Cooperative Lawyers in Wisconsin, 2008 J. DISP. RES. 203, 248 (2008). See Stacy Caplow \& Shira Scheindlin, "Portrait of a Lady": The Woman Lawyer in the 1980s, 35 N.Y.L. SCH. L. REV. 391, 422-23 (1990) (discussing female dissatisfaction with adversarial game-playing); Carrie Menkel-Meadow, Portia in a Different Voice: Speculations on a Woman's Lawyering Process, 1 BERKELEY WOMEN'S L.J. 39, 49-60 (1985) (suggesting that women are less comfortable with the adversarial system than men);.

${ }^{130}$ Irene P. Stiver, Work Inhibitions in Women 2, Work in Progress Series (1983). See also CAROL GILLIGAN, IN A DIFFERENT VOICE 42 (1982); Deborah L. Rhode, Missing Questions: Feminist Perspectives on Legal Education, 45 STAN. L. REV. 1547, 1550-51 (1993). 
differences between the way in which men and women approach lying. Males tend to lie for their own benefit ("self-oriented"), while women tend to lie to make others feel good and maintain relationships ("other-oriented"). ${ }^{131}$ It is thus not surprising that women feel less comfortable with the "self-oriented" deception inherent in traditional bargaining interactions and prefer the Collaborative Law approach which is designed to eliminate such mendacity.

The Collaborative Law movement has almost certainly excluded competitive/adversarial negotiators from their groups. This is a beneficial thing, since persons who are overtly competitive and adversarial tend to be ineffective negotiators as was found by Professors Williams and Schneider in their studies. Collaborative Law people clearly wish to include only cooperative/problem-solvers in their organizations. If they could accomplish this objective, their interactions would be pleasant and their agreements would be efficient. They would find bargaining interactions to be enjoyable, and their clients would have professional representation designed to minimize client difficulties.

What if lawyers the Collaborative Law people think are cooperative/problemsolvers are actually competitive/problem-solvers? On the surface, both types of legal negotiators behave similarly. They are always courteous and professional, and they work to generate efficient agreements. They seem to be open with their critical information,

131 See Bella M. DePaulo, Deborah A. Kashy, Susan E. Kirkendol \& Melissa M. Wyer, Lying in Everyday Life, 70 J. PERSONALITY \& Soc. Psych. 979, 987 (1996). See also Roger J. Volkema, Ethicality in Negotiations: An Analysis of Perceptual Similarities and Differences Between Brazil and the United States, 45 J. Bus. Res. 59, 64-65 (1999) (indicating that females hold stricter judgments than males with respect to what constitutes ethical negotiating behavior). 
they begin with reasonable opening offers, and seek "fair" results. Nonetheless, skilled competitive/problem-solvers disingenuously reflect the styles of cooperative/problemsolvers for the purpose of claiming more of the bargaining surplus for their own clients. Their first goal is to obtain good terms for their own side, before they work to maximize the joint returns achieved. If they are able to delude cooperative/problem-solving opponents into believing that they are also cooperative/problem-solvers, they can exploit the naïve openness of such persons. ${ }^{132}$ Such competitive/problem-solvers are really the most deceptive negotiators. They induce opponents to believe they are being completely open and direct, when their openness is limited and they are employing deceptive behavior to enhance their own circumstances. ${ }^{133}$

How can Collaborative Law participants prevent exploitation by opportunistic and manipulative competitive/problem-solvers? They can do what proficient cooperative/ problem-solvers now do and disclose their important information slowly. If they are convinced their openness is being reciprocated, they can continue to be open. On the other hand, if they suspect that their openness is not being fully reciprocated, they must behave more strategically themselves by being less open to avoid exploitation. ${ }^{134}$ They

132 See Paul Rosenberger, Note: Laissez- "Fair": An Argument for the Status Quo Ethical Constraints on Lawyers as Negotiators, 13 OHIO ST. J. DISP. RES. 611, 625-27 (1998) (lawyers who are naively open with manipulative opponents place their clients at risk).

133 See Steven Hartwell, Understanding and Dealing with Deception in Legal Negotiating, 6 OHIO ST. J. DISP. RES. 171, 173, 185-188 (1991); Lowenthal, supra Note 22, at 82 ("[T] he competitive negotiator feigning collaboration will have a substantial tactical advantage, at least in the short run."

${ }^{134}$ See Scott R. Peppet, Lawyers' Bargaining Ethics, Contract, and Collaboration: The End of the Legal Profession and the Beginning of Professional Pluralism, 90 IOWA L. REV. 475, 482-83 (2005); J. Gregory Dees \& Peter C. Cramton, Shrewd Bargaining on the Moral Frontier: Toward a Theory of Morality in Practice, 1 BUS. ETHICS Q. 143, 147-48 (1991). 
can alternatively do what many naïve cooperative/problem-solvers do and simply pretend that competitive/problem-solvers do not exist. This is a make-believe world which allows cooperative/problem-solvers to enjoy their interactions even when they compromise the interests of their own clients to enable them to avoid difficult interactions they do not like. While this approach may enable these legal representatives to avoid the riggers of true bargaining, it ill serves their clients.

Some Collaborative Law practitioners may put their own interests - and the interests of opposing counsel members of the Collaborative Law movement - ahead of the interests of their own clients in a manner that seems to contravene Rule 1.3. They are not really acting with the "reasonable diligence" required by that Rule. As Comment 1 indicates, "[a] lawyer must ... act with commitment and dedication to the interests of the client and with zeal in advocacy upon the client's behalf." ${ }^{135}$ Comment 1 goes on to acknowledge that "[a] lawyer is not bound ... to press for every advantage that might be realized for a client," 136 and it further states that "[t]he lawyer's duty to act with reasonable diligence does not require the use of offensive tactics or preclude the treating of all persons involved in the legal process with courtesy and respect."

Since proficient negotiators generally behave professionally and courteously, the commitment of Collaborative Law practitioners to behave respectfully raises no ethical dilemmas. In addition, if their commitment to cooperative interactions does not oblige them to be overly generous to clients and attorneys on the other side, they would

135 MORGAN \& ROTUNDA, supra Note 20, at 15.

136 “"'A pure client-oriented system of ethics has never been our collective experience within the bar ..." Richard C. Stanley, A Professional Modal of Ethics, 47 LOY. L. REV. 773, 789 (2001). 
similarly encounter no problems under Rule $1.3 .{ }^{137}$ Nonetheless, legal representatives should not be permitted to place their own interest in avoiding the personal discomfort associated with bargaining interactions ahead of the interests of their clients, and if they allow their dislike for real bargaining to adversely affect the interests of their clients, issues should arise under this provision. ${ }^{138}$ "[A] lawyer should never compromise the legitimate interest of a client for either the lawyer's own personal interest of the interests of any other clients." ${ }^{139}$ Nor should they be allowed to do so simply to maintain good relationships with other legal practitioners. ${ }^{140}$

"[S]ome form of deceit, at least in the broadest sense of the word, is inherent in all negotiations and the lawyer with an obligation to obtain the best result for a client cannot be expected, realistically, to negotiate outside the context of everyday convention."141

137 See John Lande, Principles for Policymaking About Collaborative Law and Other ADR Processes, 22 OHIO ST. J. DISP. RES. 619, 680-81 (2007); Christopher M.

Fairman, A Proposed Model Rule for Collaborative Law, 21 OHIO ST. J. DISP. RES. 73, 84-86 (2005).

138 See Peppet, supra Note 122, at 146-47. "If lawyers are required to respect their adversaries' rights throughout the course of representation, in the end the lawyer becomes representative of both parties and guarantor of the fairness of their transaction. The adversary system would have to be abandoned in negotiations. However desirable this may be as an ideal, it is unacceptable and unworkable for the profession today." Perschbacher, supra Note 34, at 134.

139 Lowenthal, supra Note 22, at 107 (emphasis in original).

140 See Emily T. Amanatullah, Michael W. Morris \& Jared R. Curhan, Negotiators Who Give Too Much: Unmitigated Communion, Relational Anxieties, and Economic Costs in Distributive and Integrative Bargaining, 95 J. PERSONALITY \& SOC. PSYCH. 723 (2008) (indicating that negotiators who are primarily concerned about the maintenance of personal relationships with opposing parties often obtain less beneficial results for their own side).

141 Walter W. Steele, Jr., Deceptive Negotiating and High-Toned Morality, 39 VAND. L. REV. 1387, 1399 (1986). See Scott R. Peppet, Mindfulness in the Law and ADR: Can 
Legal negotiators who ignore this reality may feel more comfortable with bargaining interactions, but they significantly risk the unknowing compromise of client interests. To the extent they naively believe that no other practitioners are exaggerating or embellishing client interests, they place their own clients at a distinct disadvantage. It is as if they are playing poker on behalf of their clients with their cards face up when they are not certain they are really able to see all of the cards being held by their opponents. By the conclusion of the poker game, the chips will most likely be on the opposing side of the table.

Collaborative Law attorneys may also encounter difficulties under Rule 1.7(a)(2) due to the "significant risk that the representation ... will be materially limited by the lawyer's responsibilities to ... a third person ..." Some Collaborative Law practitioners may be more committed to their relationships with opposing Collaborative Law counsel than they are to their own clients because of their on-going interactions with such lawyers compared to their one-time representation of current clients. If this factor were to diminish their commitment to the advancement of client interests during their negotiations with opposing counsel, significant issues could arise under this Rule.

Collaborative Law practitioners who do not wish to engage in conventional legal negotiations should be obliged to inform their clients of their unwillingness to further client interests through this distasteful process. They should also have to advise clients of their commitment to the Collaborative Law attorneys on the other side. They should explain how they hope that a commitment to the cooperative/problem-solving approach

Saints Negotiate? A Brief Introduction to the Problems of Perfect Ethics in Bargaining, 7 HARV. NEGOTIATION L. REV. 83, 91-92 (2002). 
will benefit clients by diminishing inter-client difficulties and by seeking the development of mutually efficient accords. On the other hand, they should note that competitive/problem-solvers might be able to obtain advantages for their own clients without these representatives being aware of their deceptive behavior. Clients have the right to know of attorney willingness to sacrifice client interests to serve their own desire to avoid unpleasant endeavors and to advance relationships with other lawyers. I doubt that many Collaborative Law attorneys would be willing to make such overt acknowledgements to their clients. Most will continue to naively pretend that no members of their group could possibly behave in a deceptively opportunistic fashion.

The issue bar associations have primarily focused on has concerned the disqualification provisions associated with Collaborative Law four-way agreements. This obligation is designed to maximize cooperative bargaining behavior by making it clear that negotiators who fail to achieve mutual accords may not continue to represent their clients if the matters are litigated. Given the fact that fewer than five percent - and often only one or two percent - of marital dissolution cases are resolved through formal adjudications, the disqualification provision is likely to have a minimal impact on clients. This is especially true for Collaborative Law participants who are far less likely to litigate than their competitive/adversarial cohorts. If clients are unequivocally informed of the potential impact of the disqualification provision and they knowingly consent to this term hoping to benefit from the more cooperative approach being employed by the attorneys involved, I do not believe that state bar associations should find these Collaborative Law provisions to contravene the Model Rules based solely upon this consideration. Nonetheless, bar associations should be certain that attorneys have complied with Rules 
1.3 and 1.7 by expressly discussing with clients their commitment to a process designed to avoid the give-and-take associated with traditional bargaining interactions and their focus on the continuing relationships they have with other Collaborative Law practitioners.

A recent empirical study by Professors Kathleen O'Connor and Peter Carnevale should cause Collaborative Law proponents to think about the degree to which they place joint attorney and client interests above the interests of their own clients. ${ }^{142}$ Their study dealt with so-called "common-value issues" which both sides would like to have resolved in the identical manner even though they are unaware of their positional overlap. The exercise concerned a divorce situation in which the wife desired custody of the children and the husband preferred that she have custody. Some of the negotiating dyads were completely open regarding their interests with respect to this issue. Other dyads involved participants who could be disingenuous with respect to this issue, allowing husband representatives to demand custody to enable that side to exchange this issue for other actually valued terms later during the interactions. O'Connor and Carnevale found that the individualistically motivated dyads achieved higher joint outcomes than the cooperatively motivated dyads. ${ }^{143}$ This was based upon the fact the individualistically motivated dyad participants established higher aspirations for themselves than did the cooperatively motivated dyad participants. This study would suggest that Collaborative Law negotiators should be careful not to allow their distaste for the give and take of

142 Kathleen M. O'Connor \& Peter J. Carnevale, A Nasty But Effective Negotiation Strategy: Misrepresentation of a Common-Value Issue, 23 PERSONALITY \& SOC. PSYCH. BULLETIN 504 (1997).

143 See id. at 512-513. 
traditional bargaining interactions to limit the goals they set for their own clients. If the Collaborative Law participants on both sides of such exchanges establish modest aspirations and concentrate on making sure that neither side gains at the other side's expense, both sides may end up with terms that do not maximize their potential joint returns. This would suggest that Collaborative Law negotiators should remember to establish initially beneficial goals for their respective clients before they begin to interact with opposing attorneys. The more they work to advance the interests of their own clients - while working to cooperate and maximize the joint returns achieved - the more likely they will be to generate optimal terms for both sides.

\section{CONCLUSION}

Lawyers negotiate frequently, but many feel uncomfortable with the deception inherent in most bargaining interactions. They do not like to exaggerate their positions for personal gain or to misrepresent their true client settlement intentions. Although Model Rule 4.1 prohibits the knowing misrepresentation of material fact, Comment 2 expressly notes that due to accepted bargaining conventions, advocate statements regarding client values and client settlement intentions do not concern "material fact." This exception is actually quite narrow. It merely permits "puffing" and "embellishment," but no overt or subvert misstatements of true material fact. Attorneys who misrepresent material information risk the loss of reputations for integrity which will significantly undermine their ability to practice law.

Many law school teachers and a growing group of practicing attorneys have decided to reject the conventional bargaining approach in favor of an idealized communitarian style which is based -- not upon how most legal negotiators behave -- but 
rather upon how communitarians think they should behave. A number of lawyers, particularly in the family law area, have established the Collaborative Law and the Cooperative Law movements to guarantee that participating attorneys will be entirely open and candid with each other to ensure pleasant and efficient interactions. These practitioners assume that they will all behave in a cooperative/problem-solving manner, but ignore the possibility that some members may adopt the hybrid competitive/problemsolving style designed to make them appear open when they are actually using manipulative tactics designed to enable them to claim a greater share of the joint surplus for their own side.

Collaborative Law and Cooperative Law practitioners may improperly place their own desire to avoid the riggers of conventional legal negotiating ahead of the interests of their own clients. They also want to maintain beneficial relationships with the attorneys on the other side. Because of the potential conflict created between their duties to their own clients and the interests of opposing counsel, Collaborative Law and Cooperative Law practitioners should be required to explain to their own clients the degree to which they wish to avoid personally stressful situations and to maintain harmonious relationships with opposing lawyers. Only where they obtain the informed consent of their clients to this practice should they be permitted to engage in such self-serving and unconventional bargaining. 
1 